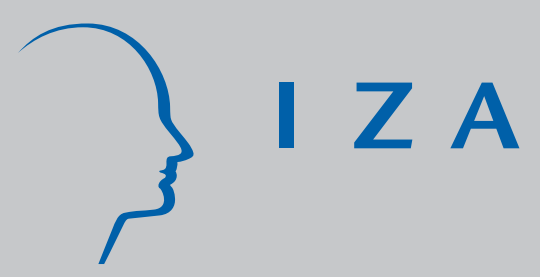

IZADP No. 1828

Public Sector Pay and Regional Competitiveness:

A First Look at Regional Public-Private Wage Differentials in Italy

Carlo Dell'Aringa

Claudio Lucifora

Federica Origo

October 2005 


\title{
Public Sector Pay and Regional Competitiveness: A First Look at Regional Public-Private Wage Differentials in Italy
}

\author{
Carlo Dell'Aringa \\ Catholic University of Milan \\ Claudio Lucifora \\ Catholic University of Milan, ERMES, CEPR \\ and IZA Bonn \\ Federica Origo \\ University of Bergamo
}

Discussion Paper No. 1828

October 2005

IZA

P.O. Box 7240

53072 Bonn

Germany

Phone: +49-228-3894-0

Fax: +49-228-3894-180

Email: iza@iza.org

Any opinions expressed here are those of the author(s) and not those of the institute. Research disseminated by IZA may include views on policy, but the institute itself takes no institutional policy positions.

The Institute for the Study of Labor (IZA) in Bonn is a local and virtual international research center and a place of communication between science, politics and business. IZA is an independent nonprofit company supported by Deutsche Post World Net. The center is associated with the University of Bonn and offers a stimulating research environment through its research networks, research support, and visitors and doctoral programs. IZA engages in (i) original and internationally competitive research in all fields of labor economics, (ii) development of policy concepts, and (iii) dissemination of research results and concepts to the interested public.

IZA Discussion Papers often represent preliminary work and are circulated to encourage discussion. Citation of such a paper should account for its provisional character. A revised version may be available directly from the author. 
IZA Discussion Paper No. 1828

October 2005

\section{ABSTRACT}

\section{Public Sector Pay and Regional Competitiveness: A First Look at Regional Public-Private Wage Differentials in Italy ${ }^{*}$}

This paper investigates regional public-private wage differentials in Italy. Following the recent wave of reforms that significantly changed wage setting and employment relations in both sectors - increasing decentralisation in collective bargaining and enforcing a "privatisation" of public sector employment contracts - we present new estimates of the public-private wage gap by geographical location. We report both 'standardised' public-private wage differentials, as well as estimates obtained using Geographically Weighted Regressions methods. We show that significant differences exist in public-private wage differentials across Italian regions, and that the latter can be partly explained by local labour market conditions affecting the private sector and only marginally the public sector. Differences in public-private wage differentials across regions are expected to determine several imbalances in terms of 'wait' unemployment and recruitment problems in the different areas.

JEL Classification: $\quad \mathrm{J} 31, \mathrm{~J} 45$

Keywords: public-private wage differentials, regional labour market, geographically weighted regressions

Corresponding author:

Claudio Lucifora

Università Cattolica

Largo Gemelli 1

20123 Milano

Italy

E-mail: claudio.lucifora@unicatt.it

\footnotetext{
Paper presented at the Workshop "PUBLIC SECTOR PAY STRUCTURES AND REGIONAL COMPETITIVENESS", ERMES-Paris2, 19th November 2004. We thank all the participants for their comments, in particular Celine Choulet, and Dominique Meurs. We are grateful to the Ministère de la Fonction Publique Francaise for financial support. The data used have been kindly provided by the Bank of Italy. Usual disclaimer applies.
} 


\section{Introduction}

There is a well established literature both in economics and sociology that has analysed regional differences in social and economic conditions in Italy. One reason for this interest in geographical economic conditions may be linked to Italy's peculiar shape, as long distances separate the Northern regions from the South of the country. Furthermore, both in terms of climate and cultural background, the North of Italy is often considered more similar to continental Europe, while Southern regions share more features with other Mediterranean countries. Significant differences are also found in regional labour markets, with almost full employment rates and labour shortages for some occupations in most of the Northern regions, matched by high unemployment rates (mainly among women and the young) in the South (Bodo and Sestito, 1991).

Among the reasons that have been traditionally put forward to explain the existence and persistence of regional differences, labour market tight regulations, centralisation of wage bargaining, coupled with (very) low geographical mobility are the most common. In particular, over the Eighties, under a labour market regime characterised by rigid wage indexation (to prices), highly centralised wage bargaining (by industry) and powerful unions, wages did not properly respond and adjust to changing local market conditions (productivity, unemployment, market prices), thus exacerbating the imbalances. Some differentiation in wage levels across regions emerged later (mainly in the private sector) as a result of the higher incidence of decentralised bargaining - at the firm and individual level, mainly concentrated in the Northern regions --, still wage differentials have never been considered large enough to compensate for the existing differences in productivity and unemployment. In this respect, both fiscal reductions and direct creation of (temporary) public jobs have been largely used as the fastest (and easiest) way to reduce unemployment in depressed areas, where the lack of infrastructures and persistent high crime rates prevented the attraction of national or foreign private capitals and the subsequent growth of a florid (and self-sustaining) productive system (Dell'Aringa and Lucifora, 2000). Preferences for national rates and equal pay structure in the public sector have also determined quite substantial public sector wage premia in the South, thus making public sector jobs even more attractive, generating a "culture of dependency" -- in which individual educational and 
occupational choices are public sector-driven -- and further exacerbating "wait" unemployment and low participation rates (Alesina et al., 2001).

Over the late Nineties a significant wave of reforms were introduced, both in the private and public sector, to allow both employment and wages to be more flexible and reactive to productivity and business conditions. In the private sector, reforms concerned the modes of recruitment of employees and the diffusion of temporary employment contracts, as well as an increased role for decentralised (firm-level) bargaining. In the public sector, the process of reform mainly concerned the so-called "privatisation" of employment relations, which was designed to make job conditions and wage setting in the public sector more similar to those prevailing in the private sector and more sensitive to productivity gains. Also, direct creation of public jobs was no longer considered as an effective active labour market measure to create selfsustaining employment and its weight in the policy mix for the South was consequently reduced. By reducing the overall rigidity of the system both in the private and public sector, these reforms may also have contributed to make wages more sensitive to local labour market conditions, although this was not the main objective.

In this paper, in the light of the institutional changes occurred over the Nineties, we intend to investigate the recent evolution of regional public-private wage differentials ${ }^{1}$. Previous studies in this area mainly focused, quite independently, on regional differences, on the one hand, and (national) on public-private wage differentials, on the other, while the issue of regional public-private wage differentials has been mostly neglected, both in Italy and elsewhere. We extend previous research on public-private wage differentials at the regional level in a number of ways. First, we consider both a longer time period and a higher number of regions. Second, we provide extensive evidence on standardised public-private regional wage differentials both using standard OLS and semi-parametric estimation methods. Finally, we use GWR (geographically weighted regression) estimation methods to account for the spatial dimension and correlation existing across regions, thus showing that the pooling of areas is rejected by the data.

\footnotetext{
${ }^{1}$ Even if the reform started in 1993 in both sectors, relevant other steps were taken also in the following years, mainly in the second half of the Nineties.
} 
The remaining part of the paper is organised as follows. Section 2 describes the institutional details related to the public sector regulation in Italy and highlights the main changes occurred in the last decade. Section 3 discusses the features of the data used in the empirical analysis and the evolution of "raw" unadjusted regional pay differentials in the private and public sector in the Nineties. Estimates of Standardised Spatial Wage Differentials are presented in section 4, while some possible explanations of such regional differences are discussed in section 5. The last section concludes.

\section{Institutional setting}

In recent decades, the public sector in most industrialised countries has undergone a relevant process of reform -- Italy was no exception -- which has been broadly referred to as "privatisation" (Elliot et al. 1999). The latter, however, took two quite different facets. The first was related to the progressive outsourcing of public industries and services, with a significant reduction of public-owned companies and public monopoly in some formerly protected industries (such as energy and telecommunications). The second concerning the reform of the terms and conditions of employment relations in the public sector. In Italy, in particular, the new set of laws introduced in 1993 to reform employment relations in the public sector were named "privatisation of public employment", thus indicating the meaning and the direction of the transformation that the legislators wanted to introduce on labour relations in this sector. Before then, the boundaries between public and private sector employment were much more clearly defined. Public employees used to benefit from a special employment status consisting of various substantive and procedural prerogatives, the most important being employment security. Other distinctive conditions also covered various aspects of the internal labour market, such as recruitment and careers -- both based on open competition to fill in job vacancies --, mobility, job classification systems and compensation schemes.

The reform in 1993 was strongly supported by the trade union movement because it widened the coverage of collective bargaining, while it reduced the importance of legislation (see Elliott et al., 1999). The shift of the regulatory power from the law to the system of collective bargaining was indeed one of the most important aspects of the 
1993 law. A public Agency (ARAN) representing public administrations in collective bargaining at the national level, replaced a multiplicity of parties that previously intervened in the bargaining process. The aim of this innovation was to insulate collective bargaining from the political and parliamentary arena. The shift in policy should have also been accompanied by a general strengthening of the managerial prerogatives of public employers and administrators. On the whole local administrative units were to be able to freely choose their own pay policy, independently from the guidelines set at national level. In this situation wage developments have become more differentiated across different public workplaces, with the degree of differentiation contingent on financial conditions of administrations and on the capacity of local unions to obtain pay increases. In principle, this further decentralisation of collective bargaining -- with less coordination from the central level - may have contributed to make wages more sensitive to local labour market conditions, but it should be noted that other institutional and political factors, in each local unit, were at work too. Existing studies of wage differentials in public sector have taken into account the different role that unions play and the different objectives that employers pursue: for example, local administrators look at their employees also as voters in local elections (Zax and Ichniowski, 1988). Unions, on their side, do not simply act as wage negotiators, as they also use their power to lobby with local administrators for both employment and wage increases. These forces seem to have been at work also in Italy (Dell'Aringa and Vignocchi, 1998). In other words, while the decentralisation of collective bargaining might have increased wage dispersion across administrative units and across regions, it is not clear whether wages have also become more flexible to local market conditions.

The reform of public employment regulation involved more than 3.5 millions of workers, corresponding to around one fourth of total employees in Italy. Table 1 reports the composition of public employment by sector in 1991 and 2002.

According to these figures, public employment is almost equally divided between central and local administrations, with a relatively high concentration in education (more than one third of total public employment), health care (around 19 percent) and local administrative bodies such as Regions, Provinces and Municipalities (between 1721 percent). While the composition of the public sector proves rather stable over the 
time span considered ${ }^{2}$, still overall employment has progressively fallen due to severe limitations imposed to new hires and workers' turnover by budget laws in order to reduce the public deficit.

\begin{tabular}{|c|c|c|}
\hline & 1991 & 2002 \\
\hline National administrations & 57.7 & 56.6 \\
\hline Central government & n.a. & 7.5 \\
\hline Education & n.a. & 35.5 \\
\hline Local administrations & 40.6 & 41.7 \\
\hline Regions, Provinces and Municipalities & 20.6 & 17.7 \\
\hline Health & 19.0 & 19.3 \\
\hline Other sectors & 1.7 & 1.6 \\
\hline TOTAL & 100.0 & 100.0 \\
\hline
\end{tabular}

Source: ISTAT \& Ragioneria di Stato

Ten years after the reform, most experts and commentators admit that, while unions have gained contractual power in negotiating at all levels (national and local), less progress has been made both in keeping the bargaining table far away from the political arena and in the capacity of public employers to improve the management of human resources to deliver better quality services (Zucaro, 2000). On the whole the results of the "privatisation" of the employment relations in the public sector are positive, but certainly much less than expected.

It is nonetheless true that the collective agreements signed by Aran and the national unions in these last ten years have introduced quite a number of changes in working conditions and in employment relations. Few examples merit to be mentioned. There has been a marked increase in the volume of non-standard employment, both fixed-term contracts and the so-called "co.co.co." (collaborazioni coordinate e continuative) ${ }^{3}$. Private temporary work agencies have been allowed to operate in the public sector. The

\footnotetext{
${ }^{2}$ The relative decrease in the share of Regions, Provinces and Municipalities was determined by the shift of administrative staff in public schools from the local level to the National government.

${ }^{3}$ Workers hired with co.co.co were formally defined as self-employed, though they often worked as standard employees
} 
recruitment of non-standard workers in the public sector is often the way to avoid the stringent conditions regulating the ordinary hiring process. Recruitment has to follow a public and open competition which is usually cumbersome in term of bureaucratic delays and costs. Moreover the number of permanent jobs is determined by formal regulation and not through collective bargaining, such that limits on hires have been introduced in the budget law in years of financial difficulties.

Rules concerning recruitment and working conditions have been partly changed in the following years and so differences with the private sector further reduced. This occurred after the collective agreements of the late 90's, which introduced a number of innovations, such as: rules for individual dismissals, paid holidays, paid and unpaid leaves and pensions. Promotion and career of workers is another field where modifications of the previous institutional setting have been substantial. First, the system of classification was modified. In the previous situation the content of jobs and occupations was detailed in national regulations such that each occupation was assigned to a specific grade in the pay scale ${ }^{4}$. Apart from overall wage increases, progression of basic pay was due only to promotion to a higher grade. Moreover all promotions to a higher level had to follow the same rules regulating recruitment from the external labour market, that is through an open competition.

The main aim of the old system was to keep labour costs under control and avoid that single administrations could use promotions to higher grades as an easy way to grant wage increases in addition to those determined sector-wide at national level. Public administrations have always opposed this system because of its time-consuming, costly, and bureaucratic procedures, and also on the ground that the power to decide on promotions and careers of employees could have been an important tool in the hands of local administrators for an efficient management of human resources (Bonaretti and Codara, 2001). This system was radically changed with the national collective agreements of the period 1997-2001. Only few grades (3-4) were kept with the same characteristics of the old ones (i.e. accessible only through a public competition open to outsiders). In between these 3-4 grades, a number of intermediate sub-grades were introduced and for them the procedure of open competition was excluded. In this case

\footnotetext{
${ }^{4}$ The number of grades (or of job classification levels) was between eight and ten, depending on the sector considered.
} 
the competition is internal, open only to incumbent employees: the criteria for selecting workers for promotion (such as merit, performance, skills, etc.) are specified in national agreements and further criteria can be added at local level through collective agreements.

The system of collective bargaining emerging from the 1993 reform is similar to that of the private sector: it takes place at two levels, one national and one firm-specific. However, in the public sector coordination between the two levels is much stronger. National agreements determine not only the basic pay for all the different grades of the sector (as the private agreements do), but also the margin for wage increases (i.e. the maximum average wage increase) that must be respected by public sector bodies in granting wage increases (the so called "wage drift") on top of the national ones. The latter is the main difference with the private sector, in which social partners can bargain over wages at firm level without any limit (Bordogna et al., 1999). Agencies and department of the public sector bargain on the distribution of the drift among different groups of workers under various forms: over-time pay, allowances for shifts and specific working conditions, performance-related pay increases, wage supplements for specific tasks in the organisation, etc. After the reform of the classification and grading system, the margin set at national level has been mainly used at the single unit level to finance internal promotions to the higher grades on the pay scale. In practice these are actually wage increases rather than real changes in workers position (in terms of more responsibility, new tasks, etc.) in the organisation of the administrative unit.

Under the pressure of unions, recent national collective agreements have included clauses that allow single administrations to bargain wages also in excess of the national guidelines (provided that the general budget of the administration is in good conditions) if wage increases are functional to improvements in efficiency and productivity. While reliable indicators for productivity have proved difficult to collect, personnel evaluation systems have been introduced by many administrations, but they have been implemented only to a very limited extent and only with great difficulties (Della Rocca, 2001). Unions, on the other side, have always opposed any forms of assessment of individual workers by claiming that these can be used in a discretionary way and generate favouritism. Managers too are in general reluctant to put into practice systems of evaluation, firstly because they themselves dislike to see their salaries linked to some 
indicator of performance, and secondly because they are convinced that the benefits obtained with economic incentives are lower than the costs due to loss of "morale", discontent, and in general to a negative reaction to criteria for selection that are considered unfair. The conclusion is that length of service has become again as the most common "objective" criteria which is followed in selecting workers for promotion. This attitude is unfortunately widespread, even if it should be recognised that there are important exceptions and that in an adequate number of public administrations things work better. On the whole, however, the general feeling is that, at least on this very important point (selectivity in promotions) things have not much improved since the reform of 1993.

One of the main features of public services is that the dispersion of wages is much lower than in the private sector. This is common to many countries, but it used to be particularly relevant in Italy, where egalitarian wage policies had a strong impact on the wage structure of the public sector. In the last ten years the situation has changed and some more earnings differentiation took place. On the one hand, the reform of the job classification system increased the number of grades in the occupational ladder. On the other hand, salaries of managers and top executives have increased substantially. Since then public managers succeeded, through their own collective agreements and by benefiting of a favourable political situation, in augmenting their own salaries much more than those of the other public employees, while they used to be very low before. In ten years' time salaries of public sector managers have almost reached those of the private sector. This was intended to give also a clear signal to the labour market of managers, but the effects have been modest. In fact, even if a public open competition is the rule to fill in vacancies, it is difficult for a manager of the private sector to pass to the public sector. The reverse is also rare. Public managers are usually selected from within and horizontal mobility between the private and the public sector is very low. The labour market is segmented and "de facto" barriers to entry are at work, making it difficult for private managers to compete with those that are already working in the public sector ${ }^{5}$.

\footnotetext{
${ }^{5}$ The question that the public opinion asks is whether in these ten years the productivity of managers has increased as much as their salaries. There is no empirical evidence on that, at least so far, but the general impression is that the answer should be negative.
} 


\section{Empirical studies, data and descriptive statistics}

The existence and persistence of significant differences in economic conditions and factors prices between Northern and Southern regions, has become known as the "North-South divide". Regional studies have been traditionally concentrating on the increasing heterogeneity across regions in economic growth, labour market conditions and productivity, discussing their effects on wage differentials and social inequality ${ }^{6}$. Empirical evidence pointed out that the rigidity of the Italian labour market did not allow regional wage differentials to properly adjust to increasing regional differences in labour productivity (Bodo and Sestito, 1991). In the same period, increasing unemployment rates in the South were accompanied by very low geographical mobility towards higher-demand (Northern) regions, making local wages even less sensitive to local economic conditions (Gavosto and Rossi, 1997; Lucifora and Origo, 1999). Recent reforms aimed at making both wages and employment more flexible (starting from the 1993 Tripartite Agreement) have so far produced marginal effects on regional wage differentials, due to the low incidence of local wage bargaining (Casadio, 1999 and 2003).

Empirical research on the public-private sector wage differential, using micro-data, has shown the existence of a (conditional) positive public wage premium ranging between 9-12 percent (depending on the period and specification considered) and varying significantly by gender (higher for women than for men) and along the wage distribution (Lucifora, 1999; Comi and Ghinetti, 2002; Lucifora and Meurs, 2004). Results are even more dispersed when endogenous sorting of workers between sectors is taken into account, but estimates are very sensitive to the estimation technique and the identification assumptions adopted (Cannari et al., 1989; Brunello and Rizzi, 1993; Bardasi, 1996 and 1998; Brunello and Dustmann, 1997; Ghinetti, 2004).

Only few empirical studies have addressed the issue of regional differences in the context of public wage premium. Alesina et al. (2001) analyse public sector employment and public sector wage differentials in a regional context, arguing that both employment and wages in the Italian public sector have been used to (implicitly) redistribute wealth from the (rich) North to the (poor) South. According to their

\footnotetext{
${ }^{6}$ For an extensive survey on empirical research on regional differences, see Favaro (2003)
} 
estimates -- based on the 1995 Bank of Italy's Survey on Households Income and Wealth (SHIW) --, the conditional public wage premium is much higher in the South than in the North of Italy (respectively, 26 percent and 12.5 percent) ${ }^{7}$. They conclude that the higher wage premium, combined with a larger share of public employment, work as a sort of "hidden subsidy" in favour of the South, and that the size of this subsidy corresponds to about half of the total public wage bill in the South.

As in most of the studies mentioned above, we use data drawn from different waves of the Bank of Italy's Survey on Households Income and Wealth (SHIW), focusing our attention on the last decade ${ }^{8}$. Detailed information on personal and job characteristics of a representative sample of around 6000 employees (for each wave) is available. Personal characteristics include gender, age, years of education and marital status, while job characteristics include economic sector, years of work experience, tenure, occupation (blue collars, white collars and managers), type of contract (whether full or part-time), (net) wages and numbers of hours worked ${ }^{9}$. Public sector employees are defined on the basis of the economic activity (broadly defined as "public administration") ${ }^{10}$. Individuals are located according to their administrative region of residence (20 regions), though for sample robustness the analysis is carried out after aggregating some of them such that we end up with 15 areas in total, covering the entire national territory ${ }^{11}$.

Before considering the empirical evidence, it is important to remind that the evolution of public-private wage differentials at the regional level can be determined by a large number of factors, such as: structural (long run) differences between sectors and business cycle effects, employment composition and workers sector choice (or workers sorting), and last but not least unobservable components affecting all the above. A

\footnotetext{
${ }^{7}$ They also point out that the differences in the two public wage premiums is very similar to the regional differences in the cost of living, suggesting that the higher public wage premiums in the South may be determined by the fact that only private wages adjust to local cost of living, while public wages do not.

${ }^{8}$ We used the 1991, 1993, 1995, 1998, 2000 and 2002 surveys.

${ }^{9}$ Empirical analysis is limited to individuals aged $15-70$.

${ }^{10}$ Due to coding reasons, it is not possible to distinguish public employees by sub-sectors. Some indirect information is available only on public sector teachers (representing around 7 percent of total public employees in the sample), due to the specific occupational code used for this category.

${ }^{11}$ Italy is divided into 20 administrative regions, characterized by quite different size. In SHIW the number of observations is very low for the smallest regions (less than 50 observations per year). For this reason, the empirical analysis was based on 15 regions (in particular, Valle d'Aosta was considered with Piemonte, Trentino Alto Adige with Friuli Venezia Giulia, Umbria with Marche, Molise with Abruzzo and Basilicata with Puglia).
} 
preliminary inspection of the data, using matching techniques, documents the role of observable factors in explaining both individual sector choice and the public wage premium $^{12}$. The so called "evaluation bias" (in our case, as discussed above, a positive effect of the public sector on wage levels) may be decomposed in three parts (Heckman et al., 1997): the bias due to differing support of the observable factors between the two groups of individuals (in our case, public and private employees), the bias due to different distribution of the observable factors and the bias due to other unobservable factors. Even if the non-experimental nature of the data does not allow to properly evaluate the relative role of these three sources of bias, a simple propensity score analysis show that differing supports may not be so relevant in our case, since more than $99 \%$ of the sample belongs to the region of common support. As far as the distribution of characteristics is concerned, a number of studies have documented the role of composition effects in public-private wage differentials (Comi et al., 2002; Meurs and Lucifora, 2004). In general, public sector employees are older and more educated than their private sector counterparts and women have a larger share (see, Annex II). Also the evolution of employment has been quite different in the two sectors over the Nineties, as turnover restrictions, in the public sector, contributed to alter age, education and gender differences as compared with the private sector. In this scenario, both the increase in female participation and higher school attainment almost exclusively affected the private sector, where the share of female employees increased by more than 10 percent points in ten years (from 29 percent in 1991 to almost 39 percent in 2002), while the average number of years of education grew from 9.5 in 1991 to 10.6 in 2002. Finally, given that public and private sector jobs differ significantly in terms of hiring requirements, job attributes and working conditions, it should be borne in mind that unobservable factors (such as preferences, job attitudes, risk aversion, etc.) may also play a role in the allocation of workers by sector and location. In the present paper, however, no attempt will be made to deal with unobservable characteristics that may affect the (endogenous) selection of workers by sector and region, and the analysis will mainly focus on the patterns determined by observable differences ${ }^{13}$.

\footnotetext{
${ }^{12}$ Results of the matching analysis are not reported but are available upon request.

${ }^{13}$ The way workers sort themselves into public and private sectors (according to unobservable factors) and the effect on the wage differential has been investigated in a number of studies, however both the magnitude and the direction of the bias are uncertain and appear to be very sensitive to model
} 
Figure 1

Real log hourly wages by sector and area in the Nineties
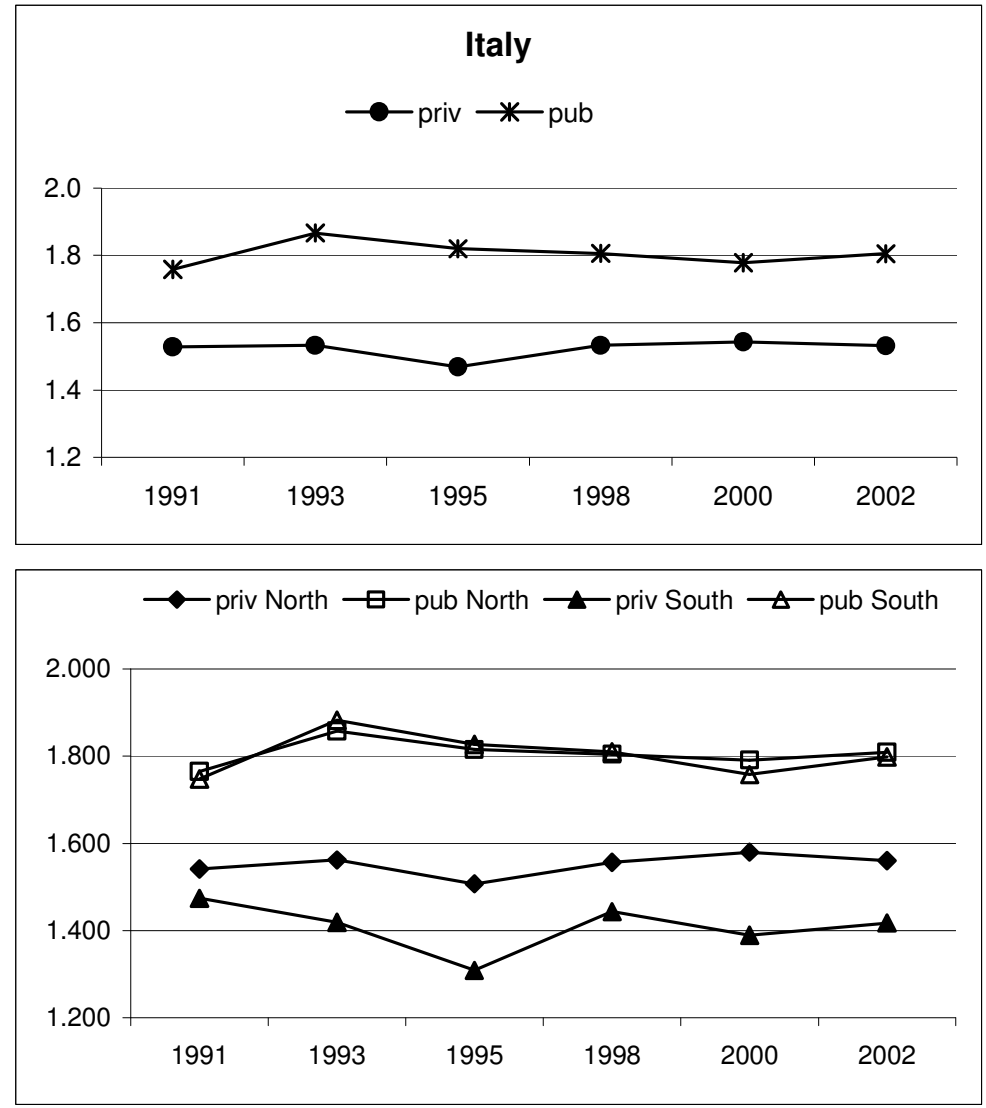

Note: All wages are in Euros.

Real wages were obtained using the consumers price deflator

With the above caveats in mind, in figure 1 we present the evolution of public and private real $(\log )$ wages ${ }^{14}$ over the Nineties, broadly distinguishing between the North and the South of Italy ${ }^{15}$. As expected, average (unconditional) private sector wages are always below public ones over the whole period considered, both in the North and in the South of Italy. Private sector wages in Southern regions are relatively lower than in the North, while no significant difference emerges in public wages paid in the two areas,

specification and estimation techniques. For example, Brunello and Dustmann (1997) found that the role of self-selection is marginal and most of the positive premium in the public sector, mainly in the case of males, can be explained by composition effects. On the contrary, Bardasi (1996 and 1998) showed that (negative) self-selection can explain a relevant share (around 20-30 percent) of the observed publicprivate wage differential for both men and women.

${ }^{14}$ The analysis is based on net wages. Nominal wages were adjusted using the national consumers price index. All the values are expressed in Euros.

${ }^{15}$ See Annex I for the classification of the administrative Italian regions in the two areas. 
thus making public-private wage differentials much larger in the South than in the North. While, over the period considered, real wages in the private sector have been quite stable, in the public sector they increased substantially, mostly in 1993 and (slightly) in 2002.

\subsection{Structural differences}

Going more deeply into regional differences, figure 2 describes the unconditional mean of real $(\log )$ hourly wages by sector and region between 1991 and 2002. Regions are ranked in descending order (from the left to the right) according to their average private wage level. All the panels point out the existence of high heterogeneity in regional public-private wage differentials, with much larger (positive) gaps in Southern regions, mainly due to the lower wages paid by the private sector. Confirming the aggregate trends previously shown, public sector wages exhibit much less dispersion across regions as compared to the private sector (in some cases public sector wages in South are higher than in the North). Private wages, conversely, show some regional dispersion, which is also (slightly) increasing over time. These trends are evident for both men and women (see Annex III).

Public-private wage differentials range from 18-22 percent in Emilia Romagna and Lombardia to 40-45 percent in Sicilia, Campania and Calabria (table 2). Note that the unconditional public-private sector wage differential is particularly low in those Northern regions where high-wage industries and services are more concentrated, while it is generally larger in some of the least industrialised Southern areas.

Differences are generally much larger in the case of women, for which the publicprivate wage differential goes from 20-30 percent in Lombardia and Emilia Romagna to more than 60 percent in Campania and Calabria. Despite of the gap in the size of the differentials by gender, the ranking of the regions is quite similar for men and women ${ }^{16}$.

\footnotetext{
${ }^{16}$ Sardegna is the only Southern region whose differentials are comparable to those registered in the North, while Umbria-Marche are more similar to the South when the wage differential for women is considered.
} 
Figure 2

Real log hourly wages by region, sector and year - Men and women
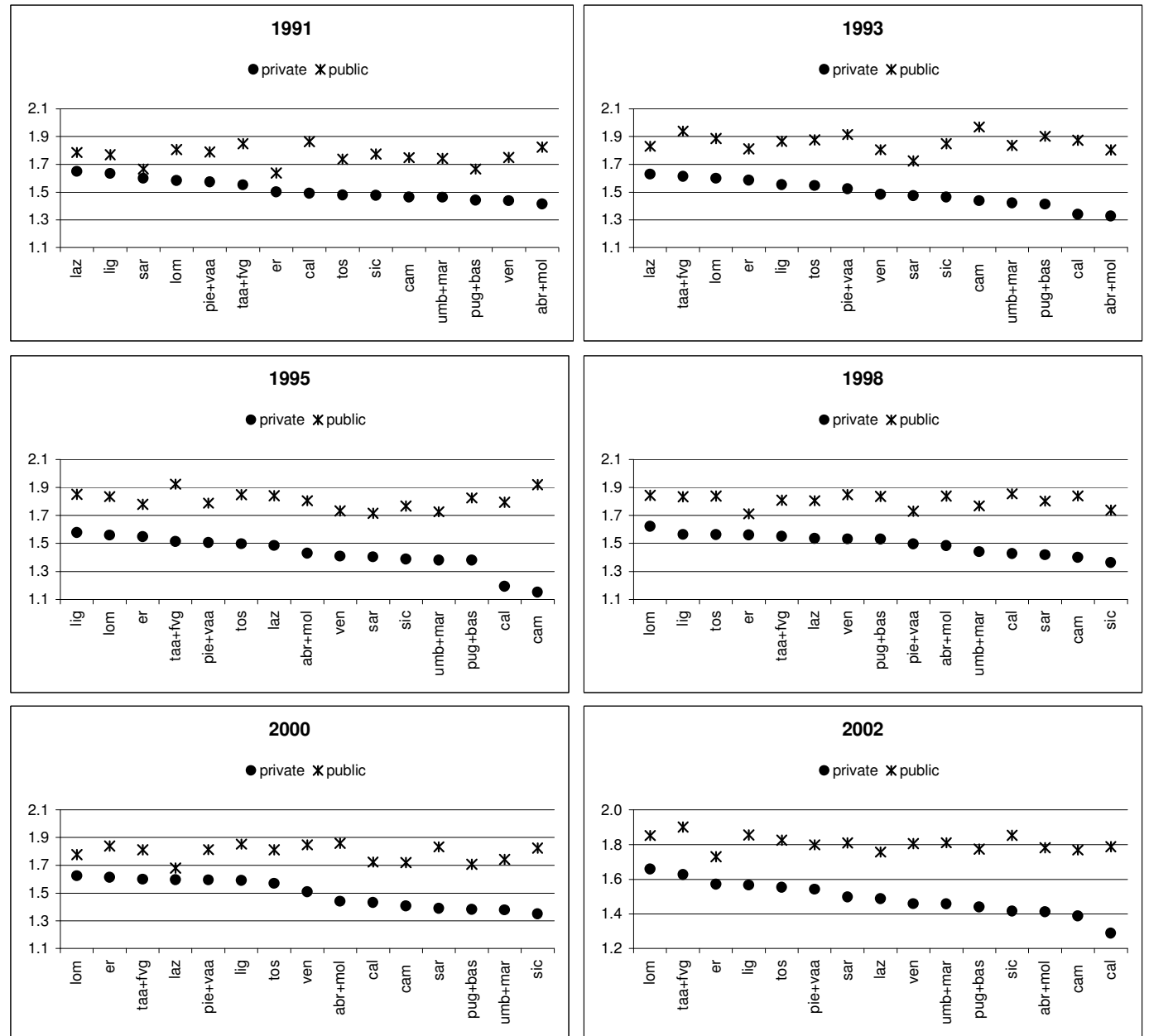

Note: regions are ordered on the basis of private wages (from the highest to the lowest)

The dispersion of public-private wage differentials across regions has been relatively stable over the Nineties for men, while it has been increasing in the case of women (figure 3). Considering the dispersion of regional wages in the private and public sector separately between 1991 and 2002, it emerges that wage dispersion across regions has been increasing only in the private sector and mainly for women. Dispersion of regional public wages has been actually reducing over the period considered, with the partial exception of male wages, which were characterised by a slight increase in regional wage dispersion between 1993 and 2000. 
Table 2

Public-private wage differentials by region and sex Pooled data (1991-2002)

(log public wage - log private wage)

\begin{tabular}{lrrr}
\hline & All & Men & Women \\
\hline pie+vaa & 0.2646 & 0.2525 & 0.3149 \\
lom & 0.2242 & 0.1946 & 0.3071 \\
taa+fvg & 0.2991 & 0.3205 & 0.3152 \\
ven & 0.3181 & 0.2748 & 0.3847 \\
lig & 0.2553 & 0.2185 & 0.3342 \\
er & 0.1775 & 0.1912 & 0.2112 \\
tos & 0.2819 & 0.2334 & 0.3731 \\
umb+mar & 0.3482 & 0.2527 & 0.4783 \\
laz & 0.2301 & 0.2028 & 0.2984 \\
abr+mol & 0.4031 & 0.3430 & 0.5159 \\
cam & 0.4604 & 0.3823 & 0.6587 \\
pug+bas & 0.3484 & 0.3001 & 0.5140 \\
cal & 0.4516 & 0.3470 & 0.7856 \\
sic & 0.3904 & 0.4086 & 0.3596 \\
sar & 0.2826 & 0.2407 & 0.3762 \\
ITALY & 0.2822 & 0.2458 & 0.3591 \\
\hline
\end{tabular}

Figure 3

Coefficient of variation of regional wages

by sector and year
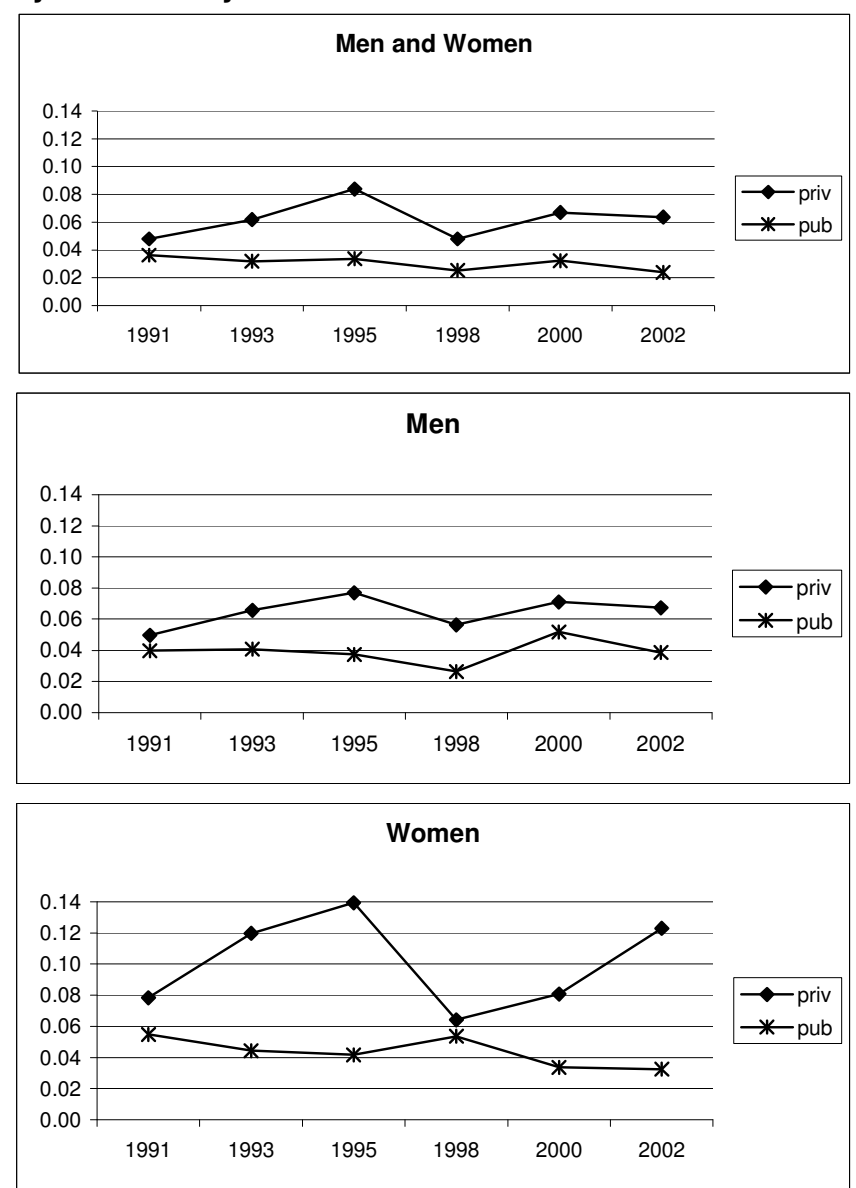
How can we explain these diverging trends? A possible explanation may be found in the (different) degree of sensitivity of public and private sector wages to local labour market conditions. Comparing the high degree of centralisation of collective bargaining in the public sector, with the relatively more decentralised pay setting procedures existing in the private sector, it is likely that private sector wages reacted to regional unemployment rates and other local business conditions more than public sector wages. In this context, at purely descriptive level, it can be interesting to look at the relationship between regional wage levels (for the public and private sector separately) and local unemployment rates over the Nineties.

\section{Figure 4}

Wage curves by sector, 1993 and 2002
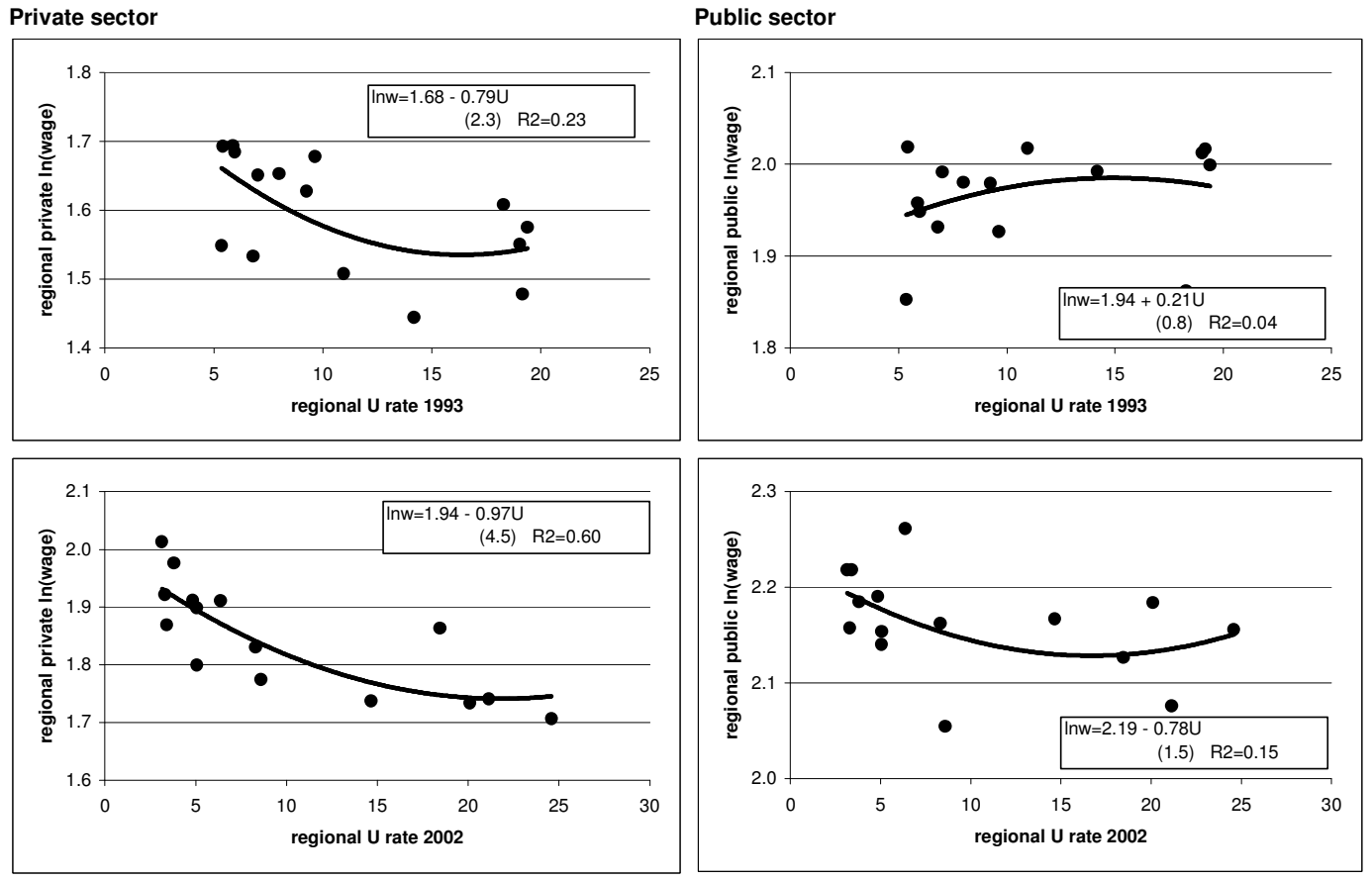

In figure 4 we plot the aggregate 'wage curve' (i.e., the relation between average regional wages and average regional unemployment rates) for the private and the public sector (both in 1993 and 2002) ${ }^{17}$. The four panels show the presence of a

${ }^{17}$ The choice of 1993 instead of 1991 is due to some relevant changes occurred in the Italian LFS in 1992. Unemployment rates are then not strictly comparable before and after that date. 
(unconditional) 'wage curve' only in the case of private wages. More specifically, regional private wages are on average lower (higher) where local unemployment is higher (lower). This negative relationship becomes even more robust over the Nineties, in line with the increased dispersion discussed above. On the contrary, the pattern for the public sector does not seem so clear cut. The slope of the wage curve is positive in 1993, while it becomes weakly negative ten years later (still not statistically significant).

\subsection{Evolution over time}

The evolution of public-private wage differentials at the local level is rather similar across all the regions considered and it follows a sort of cyclical patterns ${ }^{18}$ : increasing at the beginning of the Nineties (and peaking in 1993-95), falling in 1998 and then slightly increasing again in 2002. This cyclical pattern is shared by both men and women, even with some minor differences (either in the magnitude of the changes or in their timing) ${ }^{19}$. The cycle described above may be explained by the interaction of both economic and institutional factors (Origo, 2004), namely: a sector-specific economic cycle - i.e. the timing of wage bargaining in the two sectors --, and the employment composition effects caused by legislative interventions on employment and spending in the public sector. First, the 1992-93 economic downturn negatively affected real wage growth in the private sector, without harming purchasing power of wages paid by the public sector. The economic downturn, together with the abolition of the wage indexation system may explain part of the increase in the public-private wage gap observed in the first half of the Nineties. Second, wage growth in both sectors was also heavily influenced by the (different) timing of national collective wage bargaining between and within the two sectors ${ }^{20}$. Once a contract expires, wage growth in both sectors is also influenced by the time distribution of arrears (i.e. pay covering ex-post the spell between the end of the old contract and the introduction of the new one) and the related wage increases ${ }^{21}$. These sort of lump-sum payments may help to explain

\footnotetext{
${ }^{18}$ Detailed figures are reported in Annex IV.

${ }^{19}$ For example, in 2002 some large Northern regions (Piemonte, Lombardia and Toscana) are in fact characterized by lower male wage differentials between the two sectors than in 1991 .

${ }^{20}$ Actually the average wage growth in the private sector is determined by the combination of hundreds of different industry contracts, which usually expire (and are renewed) at different times.

${ }^{21}$ Note that lump-sum payment of arrears may be particularly high in the public sector, since delays in contract renewal are generally longer.
} 
some of the irregular patterns observed in average wage growth in the public sector (Aran, 2003). Moreover, the effect of legislative interventions aimed at containing public employment spending may have altered, by changing the natural pattern of turnover rates, wage dynamics in the public sector vis-à-vis the private sector, where such restrictions are not found.

\section{The empirical model and main results}

In this section we use a rather simplified analytical framework to estimate regional public-private wage differentials conditional on several personal characteristics and job attributes. The first step of our empirical strategy is the estimation of a traditional wage equation as follows:

$$
\ln \mathrm{W}_{\mathrm{it}}=\mathrm{X}_{\mathrm{it}} \beta+\mathrm{PUB}_{\mathrm{it}} \gamma+\mathrm{REG}_{\mathrm{it}} \delta+\left(\mathrm{PUB}_{\mathrm{it}} * \mathrm{REG}_{\mathrm{it}}\right) \lambda+\varepsilon_{\mathrm{it}}
$$

where $\mathrm{W}$ measures (net) hourly wages for the $\mathrm{i}$-th individual at time $\mathrm{t}, \mathrm{X}$ is a vector of personal and job characteristics, PUB is a dummy variable for the public sector, REG is a set of regional dummies, PUB*REG is a vector of interactions between sector and regional dummies. In this framework, we can easily retrieve an estimate of Standardised (or Conditional) Regional Wage differentials, holding personal and job characteristics constant $^{22}$. Standardised Regional Wage differentials estimated on the basis of this model are reported in table 3a-3c. Results refers to the pool data (1991-2002) ${ }^{23}$. In each table, following a specific-to-general procedure, we report estimates obtained by augmenting the $\mathrm{X}$ vector: year dummies only (column 1), personal characteristics (column 2), job attributes (column 3) and both personal and job characteristics (column 4), always including year dummies ${ }^{24}$.

\footnotetext{
${ }^{22}$ In our case the vector of personal characteristics includes: gender, age, years of education and marital status. Occupational dummies, tenure and type of contract (either full or part-time) belong to the vector of job attributes. Due to data collection and coding reasons, it is not possible to properly control for other potentially relevant job characteristics, such as economic sector and firm size: the SHIW classifies all the public employees in a unique sector ("Public administration, Defence, Education, Health and other Public Services") and does not report firm size for public employees.

${ }^{23}$ Similar results were obtained in the case of year-by-year regressions, where it is also evident the cyclical pattern discussed in the previous section. Estimates are available upon request.

${ }^{24}$ All estimates were obtained using the sample weights provided by the Bank if Italy.
} 
Table 3a

Estimates of standardised public-private wage differentials within regions, OLS, Men and women

Pooled data (1991-2002)

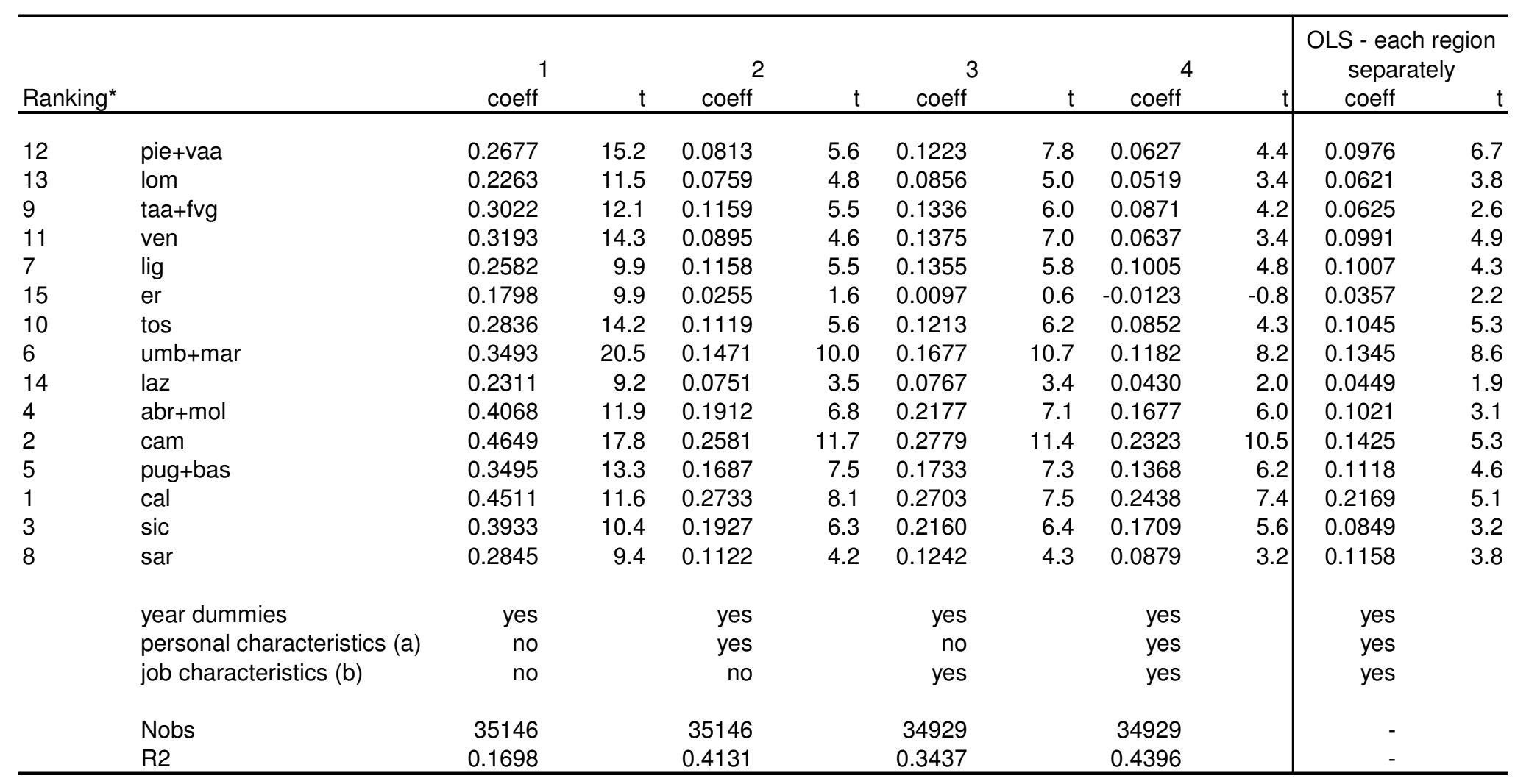

* based on public-private wage differential in col. 4. From the highest to the lowest

(a) gender, age, age squared, years of education, marital status

(b) occupation (blue collar, white collar and manager), tenure and part-time

Weighted estimates; robust t values 
Table 3b

Estimates of standardised public-private wage differentials within regions, OLS, Men

Pooled data (1991-2002)

\begin{tabular}{|c|c|c|c|c|c|c|c|c|c|c|c|}
\hline \multicolumn{2}{|c|}{ Ranking* } & ${ }_{\text {coeff }}^{1}$ & \multicolumn{3}{|c|}{2} & \multicolumn{2}{|c|}{3} & \multicolumn{2}{|c|}{4} & \multicolumn{2}{|c|}{$\begin{array}{l}\text { OLS - each region } \\
\text { separately }\end{array}$} \\
\hline 12 & pie+vaa & 0.2545 & 10.5 & 0.0577 & 2.9 & 0.0764 & 3.5 & 0.0282 & 1.5 & 0.0604 & 3.1 \\
\hline 14 & lom & 0.1963 & 6.5 & 0.0178 & 0.8 & 0.0342 & 1.4 & -0.0086 & -0.4 & 0.0021 & 1.0 \\
\hline 5 & taa+fvg & 0.3217 & 9.5 & 0.1164 & 4.0 & 0.1300 & 4.5 & 0.0850 & 3.1 & 0.0652 & 2.3 \\
\hline 11 & ven & 0.2751 & 9.5 & 0.0616 & 2.5 & 0.0816 & 3.4 & 0.0305 & 1.3 & 0.0465 & 1.9 \\
\hline 7 & lig & 0.2187 & 6.8 & 0.0915 & 3.3 & 0.0672 & 2.3 & 0.0523 & 1.9 & 0.0563 & 1.8 \\
\hline 15 & er & 0.1924 & 7.6 & 0.0004 & 0.0 & -0.0326 & -1.4 & -0.0563 & -2.7 & -0.0108 & 0.5 \\
\hline 10 & tos & 0.2346 & 9.0 & 0.0654 & 3.2 & 0.0658 & 2.8 & 0.0370 & 1.8 & 0.0445 & 1.9 \\
\hline 9 & umb+mar & 0.2533 & 12.1 & 0.0761 & 4.3 & 0.0742 & 4.1 & 0.0401 & 2.4 & 0.0622 & 3.5 \\
\hline 13 & laz & 0.2017 & 6.4 & 0.0628 & 2.3 & 0.0434 & 1.6 & 0.0234 & 0.9 & 0.0134 & 0.5 \\
\hline 4 & $\mathrm{abr}+\mathrm{mol}$ & 0.3441 & 7.7 & 0.1193 & 3.2 & 0.1463 & 3.6 & 0.0956 & 2.6 & 0.0621 & 1.5 \\
\hline 2 & cam & 0.3851 & 13.6 & 0.1787 & 7.7 & 0.1817 & 7.0 & 0.1501 & 6.5 & 0.0889 & 3.3 \\
\hline 6 & pug+bas & 0.2979 & 10.1 & 0.1186 & 4.7 & 0.1062 & 4.1 & 0.0787 & 3.2 & 0.0627 & 2.5 \\
\hline 3 & cal & 0.3471 & 8.2 & 0.1823 & 5.0 & 0.1666 & 4.3 & 0.1483 & 4.2 & 0.1427 & 3.6 \\
\hline 1 & sic & 0.4110 & 9.7 & 0.1875 & 5.6 & 0.2131 & 5.7 & 0.1679 & 5.1 & 0.0901 & 3.0 \\
\hline 8 & sar & 0.2416 & 6.2 & 0.0784 & 2.2 & 0.0796 & 2.1 & 0.0428 & 1.2 & 0.0742 & 1.8 \\
\hline & year dummies & yes & & yes & & yes & & yes & & yes & \\
\hline & personal characteristics (a) & no & & yes & & no & & yes & & yes & \\
\hline & job characteristics (b) & no & & no & & yes & & yes & & yes & \\
\hline & Nobs & 21161 & & 21161 & & 21131 & & 21131 & & - & \\
\hline & $\mathrm{R} 2$ & 0.1661 & & 0.4398 & & 0.3881 & & 0.4776 & & - & \\
\hline
\end{tabular}

* based on public-private wage differential in col. 4. From the highest to the lowest

(a) age, age squared, years of education, marital status

(b) occupation (blue collar, white collar and manager), tenure and part-time

Weighted estimates; robust t values 
Table 3c

Estimates of standardised public-private wage differentials within regions, OLS, Women

Pooled data (1991-2002)

\begin{tabular}{|c|c|c|c|c|c|c|c|c|c|c|c|}
\hline \multicolumn{2}{|c|}{ Ranking* } & $\begin{array}{c}1 \\
\text { coeff } \\
\end{array}$ & \multicolumn{3}{|c|}{2} & $\begin{array}{c}3 \\
\text { coeff } \\
\end{array}$ & \multicolumn{2}{|r|}{$\begin{array}{c}4 \\
\text { coeff } \\
\end{array}$} & 4 & \multicolumn{2}{|c|}{$\begin{array}{l}\text { OLS - each region } \\
\text { separately }\end{array}$} \\
\hline 13 & pie+vaa & 0.3217 & 12.8 & 0.1004 & 4.8 & 0.1814 & 8.1 & 0.0872 & 4.3 & 0.1379 & 6.3 \\
\hline 10 & lom & 0.3116 & 11.5 & 0.1340 & 5.9 & 0.1863 & 7.8 & 0.1125 & 5.1 & 0.1108 & 4.7 \\
\hline 14 & taa+fvg & 0.3250 & 8.6 & 0.1063 & 3.2 & 0.1677 & 4.7 & 0.0817 & 2.5 & 0.0439 & 1.1 \\
\hline 11 & ven & 0.3889 & 11.1 & 0.1258 & 4.2 & 0.2197 & 6.8 & 0.1085 & 3.6 & 0.1826 & 5.3 \\
\hline 7 & lig & 0.3468 & 8.6 & 0.1514 & 4.5 & 0.2458 & 6.7 & 0.1475 & 4.4 & 0.1425 & 3.6 \\
\hline 15 & er & 0.2197 & 8.9 & 0.0570 & 2.6 & 0.0819 & 3.6 & 0.0283 & 1.3 & 0.0727 & 2.9 \\
\hline 8 & tos & 0.3781 & 12.6 & 0.1666 & 5.2 & 0.2087 & 6.7 & 0.1376 & 4.3 & 0.1881 & 6.6 \\
\hline 5 & umb+mar & 0.4826 & 17.9 & 0.2277 & 9.4 & 0.2902 & 11.2 & 0.2018 & 8.4 & 0.2207 & 7.9 \\
\hline 12 & laz & 0.3041 & 7.7 & 0.1067 & 3.1 & 0.1547 & 4.2 & 0.0874 & 2.6 & 0.0898 & 2.3 \\
\hline 4 & $\mathrm{abr}+\mathrm{mol}$ & 0.5301 & 9.7 & 0.2940 & 6.6 & 0.3326 & 6.9 & 0.2665 & 6.1 & 0.1622 & 3.3 \\
\hline 2 & cam & 0.6734 & 10.8 & 0.4234 & 8.0 & 0.4920 & 8.8 & 0.4036 & 7.8 & 0.2919 & 4.5 \\
\hline 3 & pug+bas & 0.5293 & 9.6 & 0.2978 & 6.0 & 0.3776 & 7.3 & 0.2847 & 5.8 & 0.2194 & 3.9 \\
\hline 1 & cal & 0.7869 & 9.8 & 0.5464 & 7.5 & 0.5988 & 8.0 & 0.5175 & 7.2 & 0.3802 & 3.9 \\
\hline 9 & sic & 0.3653 & 5.8 & 0.1639 & 2.9 & 0.2216 & 3.8 & 0.1341 & 2.5 & 0.1152 & 2.0 \\
\hline 6 & sar & 0.3831 & 7.7 & 0.1665 & 3.8 & 0.2201 & 4.9 & 0.1490 & 3.4 & 0.1793 & 3.7 \\
\hline & year dummies & yes & & yes & & yes & & yes & & yes & \\
\hline & personal characteristics (a) & no & & yes & & no & & yes & & yes & \\
\hline & job characteristics (b) & no & & no & & yes & & yes & & yes & \\
\hline & Nobs & 13885 & & 13885 & & 13798 & & 13798 & & - & \\
\hline & $\mathrm{R} 2$ & 0.2187 & & 0.3876 & & 0.3385 & & 0.4066 & & - & \\
\hline
\end{tabular}

* based on public-private wage differential in col. 4. From the highest to the lowest

(a) age, age squared, years of education, marital status

(b) occupation (blue collar, white collar and manager), tenure and part-time

Weighted estimates; robust t values 
Estimated coefficients show that, when controlling for personal and job characteristics, standardised regional private-public wage differentials are much lower than what found when using raw wages. The 9-12 percent 'national' public-private wage gap usually found in the empirical literature actually hides much heterogeneity across regions: indeed, estimated public-private wage gaps by region range from 4-5 percent to 20-25 percent and, with the exception of the Sardegna region, it is usually much higher in the South. In most of the Northern regions the differential is lower than 10 percent and even lower in the largest and most industrialised regions (Piemonte, Lombardia and Emilia Romagna). Conversely, the estimated gap is above 15 percent in almost all Southern regions, reaching 20-25 percent in those characterised by high unemployment rates and larger shares of public employment (such as Calabria and Campania).

Estimates by gender (table $3 \mathrm{~b}$ for men, $3 \mathrm{c}$ for women) show that standardised wage gaps are much lower for men than for women in all the regions. Personal and job characteristics can actually explain almost all the regional wage gap for men in the Northern regions, while differences remain significant for men in the South (around 1015 percent). In the case of women standardised wage differentials remain quite high in all the regions, ranging from 9-10 percent in the North to $15-25$ percent in the South (reaching 50 percent in Calabria) ${ }^{25}$. The coefficients of determination confirm that personal and particularly job characteristics explain a higher share of total variance in the case of men.

The model specified in [1] implicitly assumes that the returns of personal and job characteristics are the same in all the regions and in both sectors.

We start releasing the first constraint (i.e., constant returns in all regions) and make the model more flexible by estimating the wage equation separately for each region ${ }^{26}$. The corresponding Standardised Regional Wage differentials are reported in column 5 of tables 3a-3c. With respect to the initial model, estimates of the public sector wage gap from the more flexible model are somewhat higher (by 1-4 percentage points) for most Northern regions, while are lower (by 3-8 percentage points) for most Southern

\footnotetext{
${ }^{25}$ Once again, Sardegna's coefficient for both men and women look more similar to those estimated for the Northern regions than for the other Southern ones.

${ }^{26}$ Note that this approach is a first intuitive step to control for spatial heterogeneity, as it is more properly done in section 4.2. with Geographically Weighted Regression models (Fotheringham et al., 2002).
} 
ones, suggesting that some of the differences in wages also go through different returns to (observed) characteristics. Still, while differences between regions are slightly reduced (now ranging from 4 percent to 21 percent), their ranking is mostly unchanged $^{27}$. Similar results emerge also when men and women are analysed separately (see last columns of tables $3 \mathrm{~b}$ and $3 \mathrm{c}$ ).

Empirical evidence from previous studies, discussed in the previous section, also pointed out that most of the public-private wage gap observed at the national level (up to 90 percent) can be attributed to differences in the observed characteristics of workers, whilst only small differences in returns exist between the two sectors. To check whether this result still holds at the regional level, we performed the Oaxaca decomposition for each region, reporting the main estimates in table $4^{28}$. These figures suggest that the share of the public-private wage gap explained by composition effects is not constant across regions, but it decreases from the North to the South (with the exception of Sicilia) and it is higher for men than for women (except for Calabria and Sicilia) ${ }^{29}$. On average, observed characteristics can explain a relevant part of regional differences in all the regions, particularly in the case of men in Emilia Romagna and Lazio. The part explained by different endowments is always much lower in the case of women and it is particularly low in Campania (around 42 percent).

The unexplained part is mainly due to different returns of gender, age, education, and occupation in the two sectors: the (negative) impact of gender is in fact much lower in the public sector, which in turn displays higher positive returns for both age (and hence work experience) and education, as opposed to the private sector. On the contrary the returns for occupations are much higher in the private sector ${ }^{30}$.

\footnotetext{
${ }^{27}$ The rank correlation index is 0.75 .

28 In this case we estimated separate wage equations for each region and sector, thus allowing different returns for the two sectors in each region. The decomposition into explained and unexplained part is based on the mean of the coeffients estimated in the two equations (Reimers, 1983). As we already mentioned, with this approach we are not taking into account the role of unobservables in determining workers' sector choice.

${ }^{29}$ This is not always true in terms of absolute values (see the second column of each panel), mainly for Central and Southern regions.

${ }^{30}$ Separate regressions for each year show that these differences in returns in the two sectors are quite stable over time, suggesting that changes in relative returns should not be the main cause of the cyclical pattern of regional public-private wage differentials registered in the Nineties. Estimates are available upon request.
} 
Table 4

Oaxaca decomposition by region

Pool data (1991-2002)

\begin{tabular}{|c|c|c|c|c|c|c|c|c|c|}
\hline & \multicolumn{3}{|c|}{ Men and women } & \multicolumn{3}{|c|}{ Men } & \multicolumn{3}{|c|}{ Women } \\
\hline & $\begin{array}{r}\text { raw wage } \\
\text { diff }\end{array}$ & $\begin{array}{r}\text { part } \\
\text { explained }\end{array}$ & $\begin{array}{r}\% \\
\text { explained }\end{array}$ & $\begin{array}{r}\text { raw wage } \\
\text { diff }\end{array}$ & $\begin{array}{r}\text { part } \\
\text { explained }\end{array}$ & $\begin{array}{r}\% \\
\text { explained }\end{array}$ & $\begin{array}{r}\text { raw wage } \\
\text { diff }\end{array}$ & $\begin{array}{r}\text { part } \\
\text { explained }\end{array}$ & $\begin{array}{r}\% \\
\text { explained }\end{array}$ \\
\hline pie+vaa & 0.2646 & 0.1834 & 69.3 & 0.2525 & 0.2139 & 84.7 & 0.3149 & 0.1861 & 59.1 \\
\hline lom & 0.2242 & 0.1486 & 66.3 & 0.1946 & 0.1582 & 81.3 & 0.3071 & 0.1895 & 61.7 \\
\hline taa+fvg & 0.2991 & 0.2387 & 79.8 & 0.3205 & 0.2798 & 87.3 & 0.3152 & 0.2468 & 78.3 \\
\hline ven & 0.3181 & 0.2211 & 69.5 & 0.2748 & 0.2146 & 78.1 & 0.3847 & 0.2355 & 61.2 \\
\hline lig & 0.2553 & 0.1816 & 71.1 & 0.2185 & 0.1582 & 72.4 & 0.3342 & 0.2349 & 70.3 \\
\hline er & 0.1775 & 0.1743 & 98.2 & 0.1912 & 0.2148 & 112.3 & 0.2112 & 0.1721 & 81.5 \\
\hline tos & 0.2819 & 0.1798 & 63.8 & 0.2334 & 0.2077 & 89.0 & 0.3731 & 0.1828 & 49.0 \\
\hline$u m b+m a r$ & 0.3482 & 0.2065 & 59.3 & 0.2527 & 0.1903 & 75.3 & 0.4783 & 0.2521 & 52.7 \\
\hline laz & 0.2301 & 0.1917 & 83.3 & 0.2028 & 0.2081 & 102.6 & 0.2984 & 0.2279 & 76.4 \\
\hline $\mathrm{abr}+\mathrm{mol}$ & 0.4031 & 0.2729 & 67.7 & 0.3430 & 0.2597 & 75.7 & 0.5159 & 0.3147 & 61.0 \\
\hline cam & 0.4604 & 0.2938 & 63.8 & 0.3823 & 0.2917 & 76.3 & 0.6587 & 0.2773 & 42.1 \\
\hline pug+bas & 0.3484 & 0.2122 & 60.9 & 0.3001 & 0.2434 & 81.1 & 0.5140 & 0.2554 & 49.7 \\
\hline cal & 0.4516 & 0.2254 & 49.9 & 0.3470 & 0.1902 & 54.8 & 0.7856 & 0.4431 & 56.4 \\
\hline sic & 0.3904 & 0.2772 & 71.0 & 0.4086 & 0.2888 & 70.7 & 0.3596 & 0.2787 & 77.5 \\
\hline sar & 0.2826 & 0.1701 & 60.2 & 0.2407 & 0.1589 & 66.0 & 0.3762 & 0.2081 & 55.3 \\
\hline
\end{tabular}

Why are returns in the two sectors further apart in the South than in the North, and mainly in the case of men? One possible explanation may rely on the different type of private jobs available in the two areas: in the North the private sector is characterised by a larger share of high productivity (high wage) jobs than in the South. These jobs usually provide higher returns, thus matching more closely the public sector wages. On the contrary, the substantial lack of this type of jobs in the private sector of Southern regions can reduce returns, thus widening the wage gap. An alternative explanation, in which the distribution of high productivity/wage jobs is the same in all areas, simply needs firms to grant higher returns to attract workers when labour shortages or skill mismatch characterise the local labour market, while lower returns are found when labour in the local labour market is in excess supply. In both cases, the institutional mechanisms operating in the public sector throughout all regions would keep down differences in returns within that sector. Note that in the light of the above discussion, we might reasonably expect labour market returns for observed characteristics between the public-private sectors to be much closer in the Northern regions, where private sector-jobs generally grant high returns, as opposed to Southern regions where returns on private sector-jobs are on average significantly lower. 


\subsection{Quantile Regression estimates}

So far econometric analysis has been focused on conditional wage means. Previous studies have already pointed out that a conditional mean approach (using traditional OLS techniques) may hide relevant heterogeneity in public-private wage differentials along the wage distribution if wage dispersion is not the same in the two sectors. If this is true, OLS assumptions might be too restrictive and quantile regression methods (QRM), by allowing the effects of the covariates to differ at different points of the wage distribution, may be preferable ${ }^{31}$. Recent empirical studies on Italy estimating the national public wage premium by QRM show that the public sector pay premium, mainly in the second half of the Nineties, declines along the wage distribution (Comi et al., 2002; Lucifora and Meurs, 2004; Origo, 2004), becoming negligible for men in the upper part of the distribution. Once controlling for personal and job characteristics at different point of the wage distribution, low wage women should be those benefiting more (in terms of wage premium) from working in the public sector.

Estimates of regional public-private wage differences by QRM for the lower and the upper quartiles actually reveal that this result mainly holds in Southern regions. As shown in table 5, the public wage premium in the lower (upper) part of the wage distribution is lower (higher) in most Northern regions, whilst it is significantly higher (lower) in most Southern ones. With a few exceptions (such as Calabria for women), this holds for both men and women ${ }^{32}$. In particular, the regional analysis shows that women in the public sector seem to benefit more in term of wage level -- as compared to their private sector counterparts - if they are located in the upper part of the distribution in the Northern regions, whereas in the South it is the lower part of the wage distribution that grants higher wage premia.

This result may be due to a number of factors, such as a higher wage dispersion and glass ceiling effects in the private sector in the North, as opposed to the competitive pressure of the irregular economy in the South. Women reaching high job positions in private firms in the North are in fact relatively more discriminated (also in terms of job

\footnotetext{
${ }^{31}$ For technical details on quantile regression estimators, see Poterba and Rueben (1994).

${ }^{32}$ Given the low standardized wage differential for men in the North, in most Northern regions the estimated public wage premium for both quartiles is not statistically significant.
} 
Table 5

Estimates of public-private wage differentials within regions, quantile regressions Pool data (1991-2002)

\begin{tabular}{|c|c|c|c|c|c|c|c|c|c|c|c|c|c|c|c|c|c|c|}
\hline & \multicolumn{6}{|c|}{ Men and women } & \multicolumn{6}{|c|}{ Men } & \multicolumn{6}{|c|}{ Women } \\
\hline & \multicolumn{2}{|c|}{ OLS } & \multicolumn{4}{|c|}{ QUANTILE REG } & \multicolumn{2}{|c|}{ OLS } & \multicolumn{4}{|c|}{ QUANTILE REG } & \multirow{2}{*}{\multicolumn{2}{|c|}{ OLS }} & \multicolumn{4}{|c|}{ QUANTILE REG } \\
\hline & & & \multicolumn{2}{|c|}{ lower quartile } & \multicolumn{2}{|c|}{ upper quartile } & \multirow[b]{2}{*}{ coeff } & \multirow[b]{2}{*}{$\mathrm{t}$} & \multicolumn{2}{|c|}{ lower quartile } & \multicolumn{2}{|c|}{ upper quartile } & & & \multicolumn{2}{|c|}{ lower quartile } & \multicolumn{2}{|c|}{ upper quartile } \\
\hline & coeff & $\mathrm{t}$ & coeff & $\mathrm{t}$ & coeff & $\mathrm{t}$ & & & coeff & $t$ & coeff & $\mathrm{t}$ & coeff & $\mathrm{t}$ & coeff & $\mathrm{t}$ & coeff & $t$ \\
\hline pie+vaa & 0.063 & 4.4 & 0.065 & 4.1 & 0.093 & 4.9 & 0.028 & 1.5 & 0.050 & 1.9 & 0.054 & 2.1 & 0.087 & 4.3 & 0.062 & 2.6 & 0.110 & 4.6 \\
\hline lom & 0.052 & 3.4 & 0.061 & 4.1 & 0.092 & 5.1 & -0.009 & -0.4 & 0.019 & 0.7 & 0.039 & 1.5 & 0.112 & 5.1 & 0.111 & 5.1 & 0.125 & 5.6 \\
\hline taa+fvg & 0.087 & 4.2 & 0.097 & 5.4 & 0.135 & 5.9 & 0.085 & 3.1 & 0.086 & 2.9 & 0.079 & 2.3 & 0.082 & 2.5 & 0.114 & 4.0 & 0.152 & 5.3 \\
\hline ven & 0.064 & 3.4 & 0.043 & 2.2 & 0.093 & 4.1 & 0.030 & 1.3 & 0.032 & 1.0 & 0.055 & 1.7 & 0.109 & 3.6 & 0.111 & 3.6 & 0.187 & 6.1 \\
\hline lig & 0.101 & 4.8 & 0.101 & 5.0 & 0.098 & 4.4 & 0.052 & 1.9 & 0.042 & 1.3 & 0.039 & 1.3 & 0.147 & 4.4 & 0.190 & 5.9 & 0.137 & 4.7 \\
\hline er & -0.012 & -0.8 & -0.003 & -0.2 & -0.033 & -1.9 & -0.056 & -2.7 & -0.056 & -2.0 & -0.074 & -3.0 & 0.028 & 1.3 & 0.016 & 0.7 & 0.000 & 0.0 \\
\hline tos & 0.085 & 4.3 & 0.082 & 4.7 & 0.111 & 4.3 & 0.037 & 1.8 & 0.025 & 0.9 & 0.022 & 0.9 & 0.138 & 4.3 & 0.154 & 5.6 & 0.202 & 5.2 \\
\hline $\mathrm{umb}+\mathrm{mar}$ & 0.118 & 8.2 & 0.109 & 7.8 & 0.126 & 7.8 & 0.040 & 2.4 & 0.076 & 3.4 & 0.050 & 2.4 & 0.202 & 8.4 & 0.185 & 8.2 & 0.231 & 10.6 \\
\hline laz & 0.043 & 2.0 & 0.065 & 3.7 & 0.078 & 3.7 & 0.023 & 0.9 & 0.048 & 1.8 & 0.046 & 1.7 & 0.087 & 2.6 & 0.095 & 3.1 & 0.134 & 4.4 \\
\hline $\mathrm{abr}+\mathrm{mol}$ & 0.168 & 6.0 & 0.163 & 7.8 & 0.168 & 7.0 & 0.096 & 2.6 & 0.099 & 3.0 & 0.042 & 1.4 & 0.266 & 6.1 & 0.246 & 6.9 & 0.298 & 9.1 \\
\hline cam & 0.232 & 10.5 & 0.294 & 17.1 & 0.162 & 8.4 & 0.150 & 6.5 & 0.234 & 9.6 & 0.071 & 3.2 & 0.404 & 7.8 & 0.436 & 12.7 & 0.302 & 9.5 \\
\hline pug+bas & 0.137 & 6.2 & 0.176 & 10.0 & 0.106 & 5.6 & 0.079 & 3.2 & 0.099 & 4.0 & 0.059 & 2.6 & 0.285 & 5.8 & 0.388 & 11.1 & 0.215 & 6.7 \\
\hline cal & 0.244 & 7.4 & 0.232 & 8.4 & 0.210 & 5.5 & 0.148 & 4.2 & 0.143 & 3.7 & 0.099 & 2.7 & 0.517 & 7.2 & 0.498 & 7.8 & 0.493 & 9.4 \\
\hline sic & 0.171 & 5.6 & 0.243 & 11.7 & 0.098 & 4.2 & 0.168 & 5.1 & 0.232 & 7.9 & 0.076 & 2.9 & 0.134 & 2.5 & 0.212 & 5.4 & 0.071 & 1.7 \\
\hline sar & 0.088 & 3.2 & 0.134 & 5.7 & 0.018 & 0.7 & 0.043 & 1.2 & 0.124 & 3.4 & -0.044 & -1.2 & 0.149 & 3.4 & 0.134 & 3.3 & 0.147 & 4.1 \\
\hline Nobs & 34929 & & 34929 & & 34929 & & 21131 & & 21131 & & 21131 & & 13798 & & 13798 & & 13798 & \\
\hline R2 & 0.440 & & 0.286 & & 0.294 & & 0.478 & & 0.296 & & 0.311 & & 0.407 & & 0.278 & & 0.294 & \\
\hline
\end{tabular}

In all models all personal and job characteristics are included as controls, as well as year dummies

Weighted estimates; OLS estimates are reported for comparison purposes 
segregation) than those in the lower part of the carrier ladder ${ }^{33}$. In the South women are much less likely to reach high job positions in the private sector (due to the structural lack of labour demand); furthermore, the presence of a developed irregular economy may produce dumping effects on private wages in the lower part of the distribution, thus making much more convenient to work (and wait for a job) in the public sector ${ }^{34}$.

\subsection{Geographically Weighted Regression Estimates}

Standardised regional public-private wage differentials obtained by traditional OLS are based on the specification of a set of regional dummies in a so called "global model". Estimates of regional differences are then based on the assumption of equal returns across regions and the existence of discontinuities occurring exactly at the administrative border of each region. Estimates of separate equation by region is a first way to allow for different returns by region, but this approach still implies discontinuity in parameter values imposed by the geographical coding through regional dummies.

Geographically Weighted Regressions (GWR) provide a fully flexible method to estimate local models without imposing ex-ante constraints on regions definition.

Consider the global wage equation specified as follows:

$$
\log \mathrm{W}_{\mathrm{it}}=\mathrm{X}_{\mathrm{it}} \beta+\mathrm{PUB}_{\mathrm{it}} \gamma+\varepsilon_{\mathrm{it}}
$$

where all the variables have the same meaning as in equation [1]. In a GWR framework, this traditional equation can be extended to allow for local (rather than global parameters) to be estimated:

$$
\log \mathrm{W}_{\mathrm{it}}=\mathrm{X}_{\mathrm{it}} \beta\left(\mathrm{u}_{\mathrm{i}}, \mathrm{v}_{\mathrm{i}}\right)+\mathrm{PUB}_{\mathrm{it}} \gamma\left(\mathrm{u}_{\mathrm{i}}, \mathrm{v}_{\mathrm{i}}\right)+\varepsilon_{\mathrm{it}}
$$

\footnotetext{
${ }^{33}$ Evidence on gender differences in Italy at the end of the Nineties showed that only $2 \%$ of managers in private firms were women, against $22 \%$ in the central public administration and $24 \%$ in local public administrations (EIRO, 2001a). Wage differences by gender are relatively high among white collars than managers (30\% vs 17\%), but the first group is highly heterogeneous and women in non manual jobs are more likely to be employed in less technical and secretarial positions (Origo, 2002). Among secretaries, no significant gender wage differences seems to emerge (EIRO, 2001b).

${ }^{34}$ Note also that wages in the SHIW are self-reported by each individual. They may then also capture cases of irregular work, mainly in areas where the underground economy is particularly developed.
} 
where $\left(\mathrm{u}_{\mathrm{i}}, \mathrm{V}_{\mathrm{i}}\right)$ denotes the geographical coordinates of the $i$-th point in space and $\beta\left(\mathrm{u}_{\mathrm{i}}, \mathrm{v}_{\mathrm{i}}\right)$ is the local estimation at this point of the continuous function $\beta(\mathrm{u}, \mathrm{v})^{35}$. Each $i$-th observation in the data-set is weighted, in an inverse order, according to its geographical distance from the location for which local parameters have to be estimated. In practice, the weighting function used is such that, within a certain bandwidth $b$, greater weight is attached to those observations "near" to the point estimated (that is, the $i$-th point) ${ }^{36}$. The optimal bandwidth is chosen on the basis of a cross-validation approach aimed at minimising the sum of estimated predicted squared errors ${ }^{37}$. Local parameters are estimated using the optimal bandwidth by fitting a weighted regression model at each point.

Using a Monte Carlo simulation ${ }^{38}$, GWR allows to test both the significance of the overall local model and spatial variability of each parameter (with respect to the global ones). From a practical point of view, due to the iterative estimation procedure, GWR can become increasingly time consuming if the data set is relatively large (i.e. approximately more than 2,000 observations). Since our (individual) pooled data set contains around 35,000 observations, we have tackled computational problems in two different ways: first, randomly restricting the original data set, and second using a twostage estimation techniques. In the first case, we randomly selected 20 percent of the observations (6,996 obs.) from the (individual) pooled sample and fitted the GWR model to the sub-sample. In the second case, we run a first-stage OLS regression on the total (individual) pooled sample controlling for personal and job attributes, then we retrieved residuals - net of individual productivity - and computed cell means by year, region, gender and public/private sector breakdowns (and by occupations in a more disaggregated version) and fitted the GWR model to the sample obtained (360 obs. and

\footnotetext{
${ }^{35}$ Note that the number of parameters to be estimated in equation [3] is actually larger than the number of observations. One way to handle this problem is to assume that each local coefficient is a function of geographical location: assuming that parameters are spatially consistent, then relatively closed observations should display similar coefficients (both in magnitude and sign).

${ }^{36}$ In our estimates, we used the following continous weighting function: $W_{j}=\exp \left(-d_{j} / b^{2}\right)$. Data is weighted according to a Gaussian curve as the distance between observations $\mathrm{i}$ and $\mathrm{j}$ increases.

${ }^{37}$ Note that if the bandwidth is too small, the weighting of all points except for i-th point itself may become negligible and a bandwidth equal to zero may be optimal. In order to avoid this case (and to properly take into account the trade-off between bias and variance), the fitted value of yi using a certain bandwidth is calculated excluding point $\mathrm{i}$.

${ }^{38}$ Under the null hypothesis, any permutation of (ui,vi) pairs among the data points is equally likely. Thus, the observed standard deviation of the parameter estimates can be compared with those obtained from randomly rearranging the data in space and repeating the GWR procedure.
} 
1041 obs.). Note that under this approach, (common) human capital an job attributes are filtered away such that regional wage differentials only reflect residual differences over and above the standard human capital returns. The main set of results from GWR estimates are reported in table 6.

Note that under this approach, (common) human capital an job attributes are filtered away such that regional wage differentials only reflect residual differences over and above the standard human capital returns. The main set of results from GWR estimates are reported in table 6. For comparison purposes, in column (1) we report OLS publicprivate wage differentials estimated from separate regional regressions -- which can be regarded as the restricted model -- in column (2) we report estimates from the randomly selected sample, while in columns (3) and (4) estimates refer to the two stage models ${ }^{39}$.

For comparison purposes, in column (1) we report OLS public-private wage differentials estimated from separate regional regressions -- which can be regarded as the restricted model -- in column (2) we report estimates from the randomly selected sample, while in columns (3) and (4) estimates refer to the two stage models ${ }^{40}$.

In all the above cases, using 50 Montecarlo replications (10 in the one-stage model) and a 2.6 to 3.6 (optimal) bandwidth, we can reject (at an high level of statistical significance) the null hypothesis of stationarity of the regional public-private wage differentials. Estimated regional public-private wage differentials range from 6 to 15 percent in column (2), from 4.5 to 22 percent in column (3) and from 1.5 to 15 percent in column (4).

Finally, in columns (5) to (8) we report the ranking of regions according to the estimated public-private wage differentials. In terms of relative ranking, GWR estimates are rather similar to the standardised regional differentials previously obtained (rank correlation coefficients are above 0.5 ). Note that even when spatial correlations are

\footnotetext{
39 In specification (a) in the first stage, we control for gender, age and its square, education and occupational dummies, while second stage is based on cell mean residuals by year, region, gender and sector (public/private). In specification (b) in the first stage, we control for gender, age and its square, education (excluding occupational dummies), while second stage is based on cell mean residuals by year, region, gender, occupation and sector (public/private).

${ }^{40}$ In specification (a) in the first stage, we control for gender, age and its square, education and occupational dummies, while second stage is based on cell mean residuals by year, region, gender and sector (public/private). In specification (b) in the first stage, we control for gender, age and its square, education (excluding occupational dummies), while second stage is based on cell mean residuals by year, region, gender, occupation and sector (public/private).
} 
accounted for in the estimation procedure, Southern regions still exhibit public-private wage differentials which are two to five times higher than those prevailing in the North.

Table 6

Standardized Regional public private wage differentials by Geographically Weighted Regressions (Pool data, 1991-2002)

\begin{tabular}{|c|c|c|c|c|c|c|c|c|}
\hline \multirow[b]{2}{*}{ Region } & \multirow[b]{2}{*}{$\begin{array}{r}\text { OLS } \\
\text { by region }\end{array}$} & \multicolumn{3}{|c|}{ GWR } & \multicolumn{4}{|c|}{ Ranking } \\
\hline & & $\begin{array}{r}20 \% \\
\text { sample }\end{array}$ & $a^{*}$ & $\mathrm{~b}^{* \star}$ & $\begin{array}{r}\text { OLS } \\
\text { by region }\end{array}$ & $\begin{array}{r}\text { GWR } 20 \% \\
\text { sample } \\
\end{array}$ & $\begin{array}{r}\text { GWR } \\
2 \text { stage a } \\
\end{array}$ & $\begin{array}{r}\text { GWR } \\
2 \text { stage b }\end{array}$ \\
\hline & (1) & (2) & (3) & (4) & (5) & (6) & (7) & (8) \\
\hline pie+vaa & 0.0976 & 0.061 & 0.045 & 0.016 & 10 & 15 & 15 & 15 \\
\hline lom & 0.0621 & 0.062 & 0.046 & 0.021 & 13 & 14 & 14 & 13 \\
\hline taa+fvg & 0.0625 & 0.080 & 0.065 & 0.043 & 12 & 9 & 9 & 9 \\
\hline ven & 0.0991 & 0.075 & 0.057 & 0.036 & 9 & 11 & 11 & 11 \\
\hline $\operatorname{lig}$ & 0.1007 & 0.063 & 0.049 & 0.021 & 8 & 13 & 13 & 14 \\
\hline er & 0.0357 & 0.074 & 0.057 & 0.034 & 15 & 12 & 12 & 12 \\
\hline tos & 0.1045 & 0.078 & 0.063 & 0.037 & 6 & 10 & 10 & 10 \\
\hline$u m b+m a r$ & 0.1345 & 0.093 & 0.089 & 0.056 & 3 & 8 & 7 & 7 \\
\hline laz & 0.0449 & 0.100 & 0.103 & 0.063 & 14 & 7 & 6 & 6 \\
\hline $\mathrm{abr}+\mathrm{mol}$ & 0.1021 & 0.107 & 0.123 & 0.079 & 7 & 6 & 5 & 5 \\
\hline cam & 0.1425 & 0.124 & 0.161 & 0.104 & 2 & 4 & 4 & 4 \\
\hline pug+bas & 0.1118 & 0.138 & 0.186 & 0.134 & 5 & 3 & 2 & 2 \\
\hline cal & 0.2169 & 0.150 & 0.221 & 0.148 & 1 & 1 & 1 & 1 \\
\hline sic & 0.0849 & 0.143 & 0.183 & 0.118 & 11 & 2 & 3 & 3 \\
\hline sar & 0.1158 & 0.116 & 0.081 & 0.051 & 4 & 5 & 8 & 8 \\
\hline \multicolumn{2}{|c|}{$\%$ sample used for each estimate } & 100 & 100 & 100 & & & & \\
\hline \multicolumn{2}{|l|}{ Monte Carlo reps } & 10 & 50 & 50 & & & & \\
\hline \multicolumn{2}{|l|}{ bandwith } & 3.6737 & 2.6038 & 3.6737 & & & & \\
\hline \multicolumn{2}{|c|}{ Test for bandwith ( $p$-value) } & 0.0 & 0.0 & 0.0 & & & & \\
\hline \multirow{2}{*}{\multicolumn{2}{|c|}{$\begin{array}{l}\text { Test for stationarity of "public" var. } \\
\text { ( } p \text { value) }\end{array}$}} & 0.028 & 0.057 & 0.041 & & & & \\
\hline & & 0.0 & 0.0 & 0.0 & & & & \\
\hline \multicolumn{2}{|c|}{ NOBS } & 6996 & $360^{\circ}$ & $1041^{\circ}$ & & & & \\
\hline \multicolumn{9}{|c|}{ Estimates spatial variability: } \\
\hline Min & 0.0357 & 0.0608 & 0.0454 & 0.0159 & & & & \\
\hline Max & 0.2169 & 0.1503 & 0.2210 & 0.1480 & & & & \\
\hline Standard deviation & 0.0427 & 0.0297 & 0.0568 & 0.0415 & & & & \\
\hline
\end{tabular}

* In the first stage, OLS with controls for human capital and job attributes; in the second stage, GWR on cell data (residuals from 1st stage) by year, region, gender and sector (public/private)

** In the first stage, OLS with controls for human capital and job attributes (excluding occupation); in the second stage, GWR on cell data (residuals from 1st stage) by year, region, gender, occupation and sector (public/private)

${ }^{\circ}$ Number of observations in the second stage; in the first stage, the number of observation is 34929

How can we explain these patterns? Are there any structural regional features or local economic conditions that can be related in a systematic way to the estimated public-private wage differentials? This issue is addressed in the next section. 
Figure 5

Conditional log hourly wages by sector and region

Pool data (1991-2002)
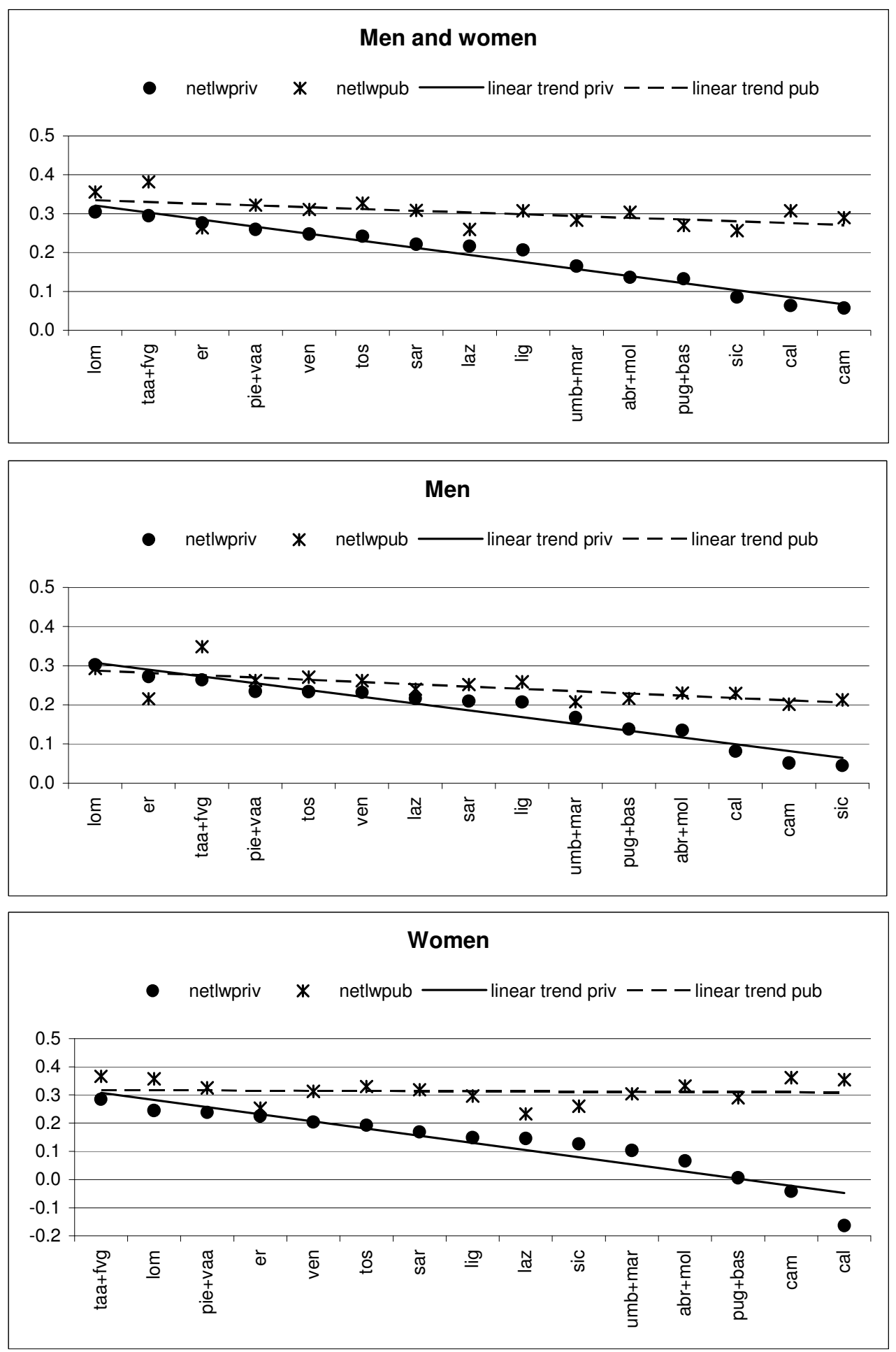


\section{Explaining the differences}

Estimated standardised regional wage differentials show the existence of a significant public wage premium mainly in Southern regions and for women. Conditional regional private and public wages plotted in figure 5 show that the first clearly decrease moving from the North to the South, while public wages are roughly constant across regions, with some Southern regions actually paying more than the Northern ones. Higher standardised regional public-private wage differentials in the South (i.e., the gap between the two plotted points for each region) seem then mainly caused by regional wage dispersion in the private sector.

It is common opinion to believe that, since private wages are set in competitive markets and should be sensitive to local business and labour market conditions, high public wage premia in Southern regions are caused by the public sector paying "wage premia" compared with the "right" local competitive wage level. However, regional private wages may also be influenced by non-competitive forces, such as monopsony and unfair competition from the irregular economy. In the case of women, gender discrimination may also play a crucial role in affecting wages in the private sector. All these factors should reduce the private sector pay below local competitive wage level, thus influencing the public wage premium. Note that in Italy all the factors mentioned above (monopsony, black economy and gender discrimination) are likely to be more relevant in the South than in the North, and in particular for women. It is than a crucial issue, even in terms of policy implications, to better understand whether the estimated standardised regional public-private wage differentials are determined by the public sector paying "too much" and/or the private sector paying "not enough" with respect to an ideal local competitive wage level. Identification of the latter may be quite difficult and it requires restrictive assumptions on the effect of local factors on wages in the two sectors.

As a preliminary step, it may be already informative to study the relation between estimated wages and labour markets conditions, life quality and amenities at the local level using a simple descriptive approach. According to the compensating differentials theory, individuals living in regions with some "unpleasant" attributes, under certain assumptions, need to be adequately compensated for the disutility caused by these 
disamenities, if they are to remain in the same area and not move to - ceteris paribus -more attractive areas (in terms, for example, of climate, air pollution, crime rates, quality of local services, etc.). In this context, high unemployment rates may be considered as a form of "disamenity" for people looking for a job: high unemployment regions should then pay higher wages than low unemployment ones to compensate individuals for the disutility associated with the risk of becoming unemployed (Harris and Todaro, 1970). However, in a bargaining framework high local unemployment rates may exert a negative effect on unions wage bargaining power (since union members are more likely to become unemployed) and the correlation between local unemployment and wages should be negative (McDonald and Solow, 1981; Oswald, 1985).

Hence, conditional on a number of factors such as structural features and other compositional effects, economic theory predicts that at the local level there should be a (statistically significant) relationship between wage levels and labour market conditions, cost of living, other amenities (Blanchflower and Oswald, 1990; 1994).

Table 7 reports some simple correlations between the estimated regional wages by sector and some regional indicators of the factors discussed above, using various indicators for both local amenities and labour market conditions. More specifically, for each region, we measured local amenities using the number of days of rains in a year (as a proxy for local attractiveness in terms of climate and weather, assuming that people prefer to live in sunny areas), the local crime rate (as a proxy for local safety) and the price of houses (as a proxy for local cost of living). As an alternative to the above indicators, we also used an overall indicator of "quality of life" which is supposed to capture different aspects of local conditions, such as: demographic structure, standard of living, business conditions and labour markets, environment and quality of local public services, crime and leisure ${ }^{41}$. Finally, we introduced local labour market indicators such as: overall unemployment, youth unemployment (15-24 years old), female participation, share of employment in the public sector and share of irregular employment.

\footnotetext{
${ }^{41}$ Definitions and statistics of regional indicators are reported in Annex VI. Unfortunately no official data on public sectors jobs is available in Italy at the moment.
} 
Table 7

Pairwise correlations, conditional wages, 2002

\begin{tabular}{|c|c|c|c|}
\hline \multicolumn{4}{|c|}{ Men and women } \\
\hline & log priv. w & $\log$ pub. w & dif. $w$ \\
\hline log priv. w & 1 & $0.5272^{*}$ & $-0.9058^{\star}$ \\
\hline U rate & $-0.8216^{*}$ & -0.3676 & $0.7769^{\star}$ \\
\hline Youth U rate & $-0.8284^{*}$ & -0.4222 & $0.7576^{\star}$ \\
\hline Female activity rate & $0.8357^{*}$ & 0.4341 & $-0.7602^{\star}$ \\
\hline$\%$ public employment & $-0.7943^{*}$ & -0.423 & $0.7173^{\star}$ \\
\hline$\%$ irregular employment & $-0.8898^{*}$ & -0.3827 & $0.8490^{*}$ \\
\hline days of rain & $0.6599^{*}$ & $0.5748^{*}$ & -0.4845 \\
\hline house prices & $0.6061^{*}$ & 0.2177 & $-0.5997^{\star}$ \\
\hline crime rates & 0.0722 & -0.0386 & -0.1036 \\
\hline life quality & $0.8763^{*}$ & $0.6307^{*}$ & $-0.7096^{*}$ \\
\hline \multicolumn{4}{|c|}{ Men } \\
\hline & log priv. w & log pub. w & dif. w \\
\hline log priv. w & 1 & $0.6713^{*}$ & $-0.8831^{*}$ \\
\hline U rate & $-0.8215^{*}$ & -0.501 & $0.7576^{\star}$ \\
\hline Youth U rate & $-0.8251^{*}$ & $-0.5293^{*}$ & $0.7444^{*}$ \\
\hline Female activity rate & $0.8530^{*}$ & 0.501 & $-0.7987^{\star}$ \\
\hline \% public employment & $-0.8031^{*}$ & -0.4209 & $0.7840^{\star}$ \\
\hline$\%$ irregular employment & $-0.8829^{*}$ & $-0.5152^{*}$ & $0.8289^{*}$ \\
\hline days of rain & $0.6313^{*}$ & $0.6111^{*}$ & -0.4389 \\
\hline house prices & $0.6470^{*}$ & 0.2767 & $-0.6708^{*}$ \\
\hline crime rates & 0.0768 & -0.004 & -0.1028 \\
\hline life quality & $0.8872^{*}$ & $0.6975^{*}$ & $-0.7191^{*}$ \\
\hline \multicolumn{4}{|c|}{ Women } \\
\hline & log priv. w & log pub. w & dif. w \\
\hline log priv. w & 1 & -0.1421 & $-0.9530^{\star}$ \\
\hline U rate & $-0.7764^{*}$ & 0.0810 & $0.7309^{\star}$ \\
\hline Youth U rate & $-0.7692^{*}$ & 0.0149 & $0.7042^{\star}$ \\
\hline Female activity rate & $0.7073^{*}$ & 0.0224 & $-0.6364^{*}$ \\
\hline$\%$ public employment & $-0.6853^{*}$ & -0.1152 & $0.5880^{*}$ \\
\hline$\%$ irregular employment & $-0.8534^{*}$ & 0.0867 & $0.8027^{\star}$ \\
\hline days of rain & $0.6196^{*}$ & 0.2707 & -0.4806 \\
\hline house prices & 0.4791 & -0.0168 & -0.4408 \\
\hline crime rates & 0.0869 & -0.1039 & -0.1106 \\
\hline life quality & $0.7439^{*}$ & 0.1894 & $-0.6186^{\star}$ \\
\hline
\end{tabular}

${ }^{*}$ statistically significant at $5 \%$

Statistics on regional indicators in Annex V

Given the lack of consistent time series for the whole period, the set of indicators usually refers to late $1990 \mathrm{~s}$ and 2000 s averages. Overall, the figures in the table (referred to conditional wages in 2002) show that some (statistically significant) relations do exist between (conditional) private regional wages and both amenities and labour market conditions at the local level. 
Figure 6

Conditional public-private wage gap and unemployment by region in the Nineties
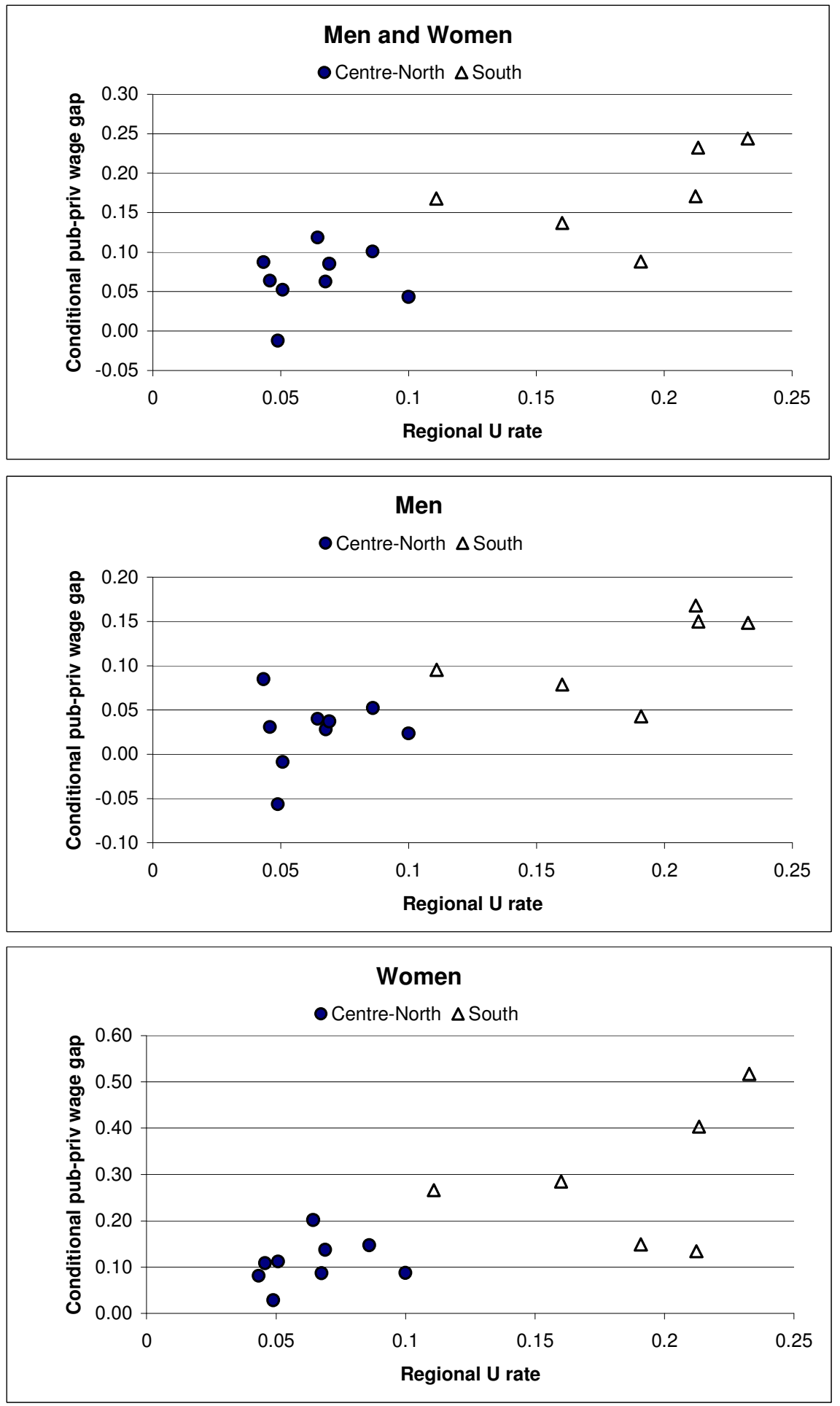
Private wages are in fact higher in low unemployment regions, where female participation is higher and where the share of both public and irregular employment is lower. Furthermore, there seems to be a positive spatial correlation between private wages and local weather, house prices and the overall quality of life. Public wages are weakly associated to local amenities, but they do not show any statistically significant correlation with local labour market conditions ${ }^{42}$. Crime rates are not significantly correlated with estimated wages in either of the two sectors.

The implication of the above discussion in terms of standardised regional publicprivate wage differentials is the existence of a (statistically significant) positive relationship with unemployment rates (as clearly depicted in figure 6), while the correlation with house prices and life quality is significantly negative (see last column in table 7).

\section{Concluding remarks}

This paper has investigated the evolution of regional public-private wage differentials in Italy. Taking into account the wave of reforms that have changed wage setting and employment relations in both sectors, we documented the significant differences existing in public-private wage differentials across Italian regions. The evolution of the public sector wage gap, over the Nineties, was shown to have followed a cyclical pattern influenced (among other things) by institutional features, such as: the incidence of wage bargaining (in both sectors) and the delays in contracts renewals in the public sector. Results showed that composition effects (in terms of different average personal and job characteristics) can actually explain almost all the regional wage gap for men in the Northern regions, while differences remain significant for men in the South (between 10-15 percent) and for women in all regions (between 9-10 percent in the North, 15-25 percent in the South). One explanation we provide for the above findings lies in the existence of different type of private jobs in the two areas: a larger (smaller) share of high productivity/high wage jobs in the North (South) providing higher returns; such that the public-private sector wage differential observed (in the

\footnotetext{
${ }^{42}$ In the case of men public wages are negatively correlated with local youth unemployment rates and the incidence of irregular employment.
} 
North) is smaller. Alternatively, a further explanation has been based on the existence of labour shortages or skill mismatch in the Northern local labour market, which - in the attempt to attract workers -- drives (private) returns upwards, thus closing the differences in public and private sector wages. Finally, standardised public-private wage differentials have been shown to be higher in regions with better local amenities but with also higher unemployment, though (as discussed above) these effects are mainly driven by private wages, as public wages remain rather insensitive to (most) local labour market conditions.

On the basis of these results, the labour market reforms implemented in Italy during the Nineties seem to have produced only moderate effects on the regional dispersion of public-private wage differentials -- as most of the changes occurred in the private sector, with little (or no) effects on the public sector -, if not exacerbating regional imbalances in terms of 'wait' unemployment in the South and recruitment problems in the North.

Pay determination in the public sector has remained quite centralised and wage differentials are still rigid in responding to market pressure. At present the central government still plays the leading role in the bargaining process: once an agreement is reached in this sector, the same pay increases are "de facto" extended to the other public sub-sectors, without relevant modifications. Moreover, no pay differentiation across different regions is allowed for in national agreements. This system would benefit from more decentralisation, if local labour market conditions have to play a role. National agreements do not need to be discarded, but they should (at least) be less important in determining pay increases: ideally they could be a point of reference with some further (flexible) negotiations at the local level.

A more decentralised pay determination system should be accompanied by more freedom for public managers in recruiting, retaining and motivating public employees. In Italy the attempts to mimic the private sector best practices by "empowering" management have been constrained by institutional, administrative and legal regulation (Dell'Aringa and Vignocchi, 1998). At the same time most public sector managers are lacking the necessary skills and experience for bargaining at the local level. In this context, in which the power of insiders is very strong (also in political terms), a more decentralised bargaining not only would not be able to keep control over labour costs, 
but also would lack flexibility in setting wage differentials. Some move in this direction may be still possible and not too costly, given that differences exist in terms of organisation, types of occupations, and employment relations. These differences may make reforms easier to implement in some sub-sectors than in others, and some forms of decentralisation might be favoured without incurring all the risks outlined above. An "organised decentralisation", of the sort outlined in some recent work (Traxler et al., 2001), could combine tight control on overall expenditures with margin for employers to negotiate some wage flexibility at local level and promote convergence in publicprivate pay determination. Such convergence seems more difficult for those occupational groups (such as teachers or doctors) who still are not highly represented in the private sector, and whose pay determination arrangements are more likely to continue to reflect, for some time ahead, their distinct national occupational identities and labour market characteristics. 


\section{References}

Aran (1999), Newsletter Aran sulle retribuzioni, Roma.

Aran (2003), "La crescita retributive pubblica e private: un confronto di medio periodo", in Rapporto trimestrale sulle retribuzioni dei pubblici dipendenti, July, Roma.

Alesina, A., Danninger, S. and Rostagno, M. (2001), "Redistribution through public employment: the case of Italy, IMF Staff Papers, 48, 3.

Bardasi, E. (1996), "I differenziali salariali tra pubblico e privato: un'analisi microeconometrica", Lavoro e Relazioni Industriali, 3.

Bardasi, E. (1998), "Dispersione salariale e differenziali retributivi: i settori pubblico e privato nella prima metà degli anni '90", in Dell'Aringa, C. (ed), op. cit.

Blanchflower, D. and Oswald, A. (1990) “The Wage Curve", Scandinavian Journal of Economics, 92.

Blanchflower, D. and Oswald, A. (1994), The Wage Curve, MIT Press: Cambridge Mass.

Bodo, G. and Sestito, P. (1991), Le vie dello sviluppo. Dall'analisi de dualismo territoriale: una proposta per il Mezzogiorno, Il Mulino, Bologna.

Bonaretti, M., and Codarda, L. (eds.), (2001), Ripensare il lavoro pubblico, Rubbettino, Catanzaro.

Bordogna, L. (2002), Contrattazione integrativa e gestione del personale nelle pubbliche amministrazioni. Un'indagine sull'esperienza del quadriennio 1998-2001, Franco Angeli.

Bordogna, L., Dell'Aringa, C. and Della Rocca, G. (1999), "Italy", in Bach, S., Bordogna, L., Della Rocca, G. and Winchester, D. (eds), Public Service Employment Relations in Europe, Routledge, London.

Brunello, G. and Dustmann, C. (1997), "Le retribuzioni nel settore pubblico e privato in Italia: un paragone basato su dati microeconomici”, in DEll'Aringa, C. (ed)., op. cit.

Brunello, G. and Rizzi, D. (1993), “ I differenziali retributivi nel settore pubblico e privato in Italia: un' analisi cross-section", Politica Economica, 3.

Cannari, L., Pellegrini, G. and Sestito, P. (1989), "Redditi da lavoro dipendente: un'analisi in termini di capitale umano", Temi di Discussione, Banca d'Italia, 124.

Casadio, P. (1999), "Diffusione dei premi di risultato e differenziali retributivi territoriali nell'industria", Lavoro e Relazioni Industriali, 1.

Casadio, P. (2003), "Wage Formation in the Italian private sector after the 1992-93 Income Policy Agreements", in Fagan, G., Mongelli, P. and Morgan, J. (eds), Institutions and Wage Formation in the New Europe, Edward Elgar, Northampton.

Comi, S., Ghinetti, P. and Lucifora, C. (2002), "La distribuzione dei salari nel settore pubblico e nel settore privato:Un'analisi disaggregata", in Mobilità Salariale ed Occupazionale in Italia, Vita e Pensiero.

Comi, S. and Ghinetti, P. (2002), "La distribuzione dei salari in Italia: un confronto tra pubblico e privato", Rivista Internazionale di Scienze Sociali, 110. 
Dell'Aringa, C. (ed., 1994), Le carriere retributive nel pubblico impiego, Franco Angeli.

Dell'Aringa, C. (ed, 1997), Rapporto Aran sulle retribuzioni 1996, Franco Angeli.

Dell'Aringa, C. (ed, 1998), Rapporto Aran sulle retribuzioni 1997, Franco Angeli.

Dell'Aringa, C., Origo, F. and Samek, M. (1999), "Il mercato del lavoro nel Mezzogiorno: il ruolo del costo e della flessibilità del lavoro", L'Industria, 2.

Dell'Aringa C. and Vignocchi, C. (1998), "Employment and Wage Determination for Municipal Workers", Working Paper Istituto di Economia dell'Impresa e del Lavoro, 22, Università Cattolica, Milano.

Dell'Aringa C. And Lucifora, C. (2000), "Inside the Black-box: Labour Market Institutions, Wage Formation and Unemployment in Italy", Rivista di Politica Economica, N.3.

Della Rocca, G. (ed, 2001), La valutazione e la retribuzione delle prestazioni, Rubbettino, Catanzaro.

Elliot, R., Lucifora, C. and Meurs, D. (1999), Public sector pay determination in the European Union, Macmillan, London.

EIRO (2001a), Gender discrimination in professional career - Italy, April.

EIRO (2001b), Wage differences between men and women - Italy, April.

Faini, R. (1995), "Stesso lavoro,diverso salario? Flessibilità, gabbie salariali e ruolo del sindacato nel Mezzogiorno", in Il Sole 24 Ore (ed), Le Nuove Frontiere della Politica Economica, Milan.

Favaro, D. (2003), "Divari territoriali, sviluppo e convergenza regionale" in Lucifora, C. (ed), Mercato, Occupazione e Salari: la Ricerca sul Lavoro in Italia, Mindadori.

Fotheringham, A., Brunsdon, C. and Charlton, M. (2002), Geographically Weighted Regressions. The analysis of spatially varying relationships, Wiley.

Gavosto, A. and Rossi, F. (1997), "Livelli di contrattazione e differenziali retributivi", in De Nardis, S. and Galli, G. (eds), La disoccupazione italiana, Il Mulino, Bologna.

Ghinetti, P. (2004), "The effect of working in the public sector when education and sector choices are endogenous: an empirical investigation for Italy", paper presented at the XIX AIEL Conference, Modena, 23-24 ${ }^{\text {th }}$ September.

Harris, J. and Todaro, M. (1970), "Migration, unemployment and development: a two sectors analysis", American Economic Review, 100.

Heckman, J., Ichimura, H. and Todd, P. (1997), "Matching as an econometric evaluation estimator: evidence from evaluating a job training program" Review of Economic Studies, 64.

Henley, A. and Thomas, D. (2001), "Public service employment and the publicprivate wage differential in British regions", Regional Studies, 35, 3.

IRS-CNEL (eds, 1997), Rapporto sulle retribuzioni e sul costo del lavoro, Giuffrè. 
Lucifora, C. (1999), "Rules vs bargaining: pay determination in the Italian public sector", in Elliot, R., Lucifora, C. and Meurs, D., op. cit.

Lucifora, C. and Meurs, D. (2004), "The public sector pay gap in France, Great Britain and Italy", IZA Discussion Papers, 1041.

Lucifora, C. and Origo, F. (1999), "Wage differentials and unemployment in Italy: a regional perspective", in EC (ed), Wages and Employment, Brussels.

Lucifora, C. and Origo, F. (1999), “Alla ricerca della flessibilità: un'analisi della curva dei salari in Italia”, Rivista Italiana degli Economisti, 1.

McDonald, I. and Solow, R. (1981), "Wage bargaining and employment", American Economic Review, 71.

Origo, F. (2002), "Struttura ed evoluzione dei differenziali salariali in Italia nella seconda metà degli anni Novanta" in CNEL (ed), Contrattazione, Retribuzioni e costo del lavoro in Italia, 2000-2001, Documenti CNEL, 23.

Origo, F. (2004), "Il premio salariale del settore pubblico negli anni Novanta", in CNEL-CESOS (eds), Contrattazione, retribuzioni e costo del lavoro in Italia. Rapporto 2002-2003, Documenti CNEL, 43.

Oswald, A. (1985), "The economic theory of the trade unions: an introductory survey", Scandinavian Journal of Economics, 87.

Poterba, L. e Rueben, K. (1994), "The distribution of public sector wage premia: new evidence using quantile regression methods", NBER Working Papers, 4734.

Reimers, C. (1983), "Labor market discrimination against hispanic and black men", The Review of Economics and Statistics, 65.

Traxler, F., Blaschke, S. and Kittel, B. (2001). National Labour Relations in Internationalized markets - A comparative study of institutions, change and performance. Oxford University Press

Zax J, and Ichniowski, C. (1988), The Effect of Public Sector Unionism on Pay, Employment, Department Budgets and Municipal Government Expenditures, In : R. B. Freeman and C. Ichniowski, eds., When Public Sector Workers Unionize, The University Chicago Press.

Zucaro, A. (2000), "L'attuazione della riforma del pubblico impiego", Giornale di Diritto Amministrativo, Quaderni, 2. 


\begin{tabular}{ll}
$\begin{array}{l}\text { Annex I } \\
\text { Italian Regions }\end{array}$ & \\
\hline Name & Acronym \\
\hline North & \\
Piemonte \& Valle d'Aosta & pie+vaa \\
Lombardia & lom \\
Trentino A. A. \& Friuli V. G. & taa+fvg \\
Veneto & ven \\
Liguria & lig \\
Emilia Romagna & er \\
Toscana & tos \\
Umbria \& Marche & umb+mar \\
Lazio & laz \\
South & \\
Abruzzo \& Molise & abr+mol \\
Campania & cam \\
Puglia \& Basilicata & pug+bas \\
Calabria & cal \\
Sicilia & sic \\
Sardegna & sar \\
\hline
\end{tabular}


Annex II

Average personal and job characteristics of private and public employees

\begin{tabular}{lrrrrrr}
\hline & \multicolumn{2}{c}{$\mathbf{1 9 9 1}$} & \multicolumn{2}{c}{$\mathbf{2 0 0 2}$} & \multicolumn{2}{c}{ Pool data } \\
& private & public & private & public & private & public \\
\hline & & & & & & \\
\% female & 29.7 & 49.2 & 38.9 & 49.8 & 35.4 & 48.5 \\
age (years) & 36.7 & 40.0 & 37.7 & 43.8 & 36.8 & 41.8 \\
education (years) & 9.5 & 12.5 & 10.6 & 12.7 & 10.1 & 12.6 \\
\% married & 63.3 & 71.1 & 57.4 & 73.7 & 60.1 & 74.7 \\
work experience (years) & 18.1 & 18.1 & 18.1 & 21.9 & 17.9 & 20.0 \\
\% blue collars & 59.5 & 16.2 & 56.3 & 13.4 & 58.4 & 15.1 \\
\% white collars & 39.0 & 79.8 & 37.1 & 74.2 & 35.2 & 74.6 \\
\% managers & 1.5 & 3.9 & 6.7 & 12.4 & 6.4 & 10.3 \\
\% part-time & 4.3 & 3.9 & 11.1 & 4.4 & 8.4 & 2.9 \\
weekly hours worked & 40.7 & 36.2 & 38.7 & 35.1 & 39.6 & 35.0 \\
\hline
\end{tabular}




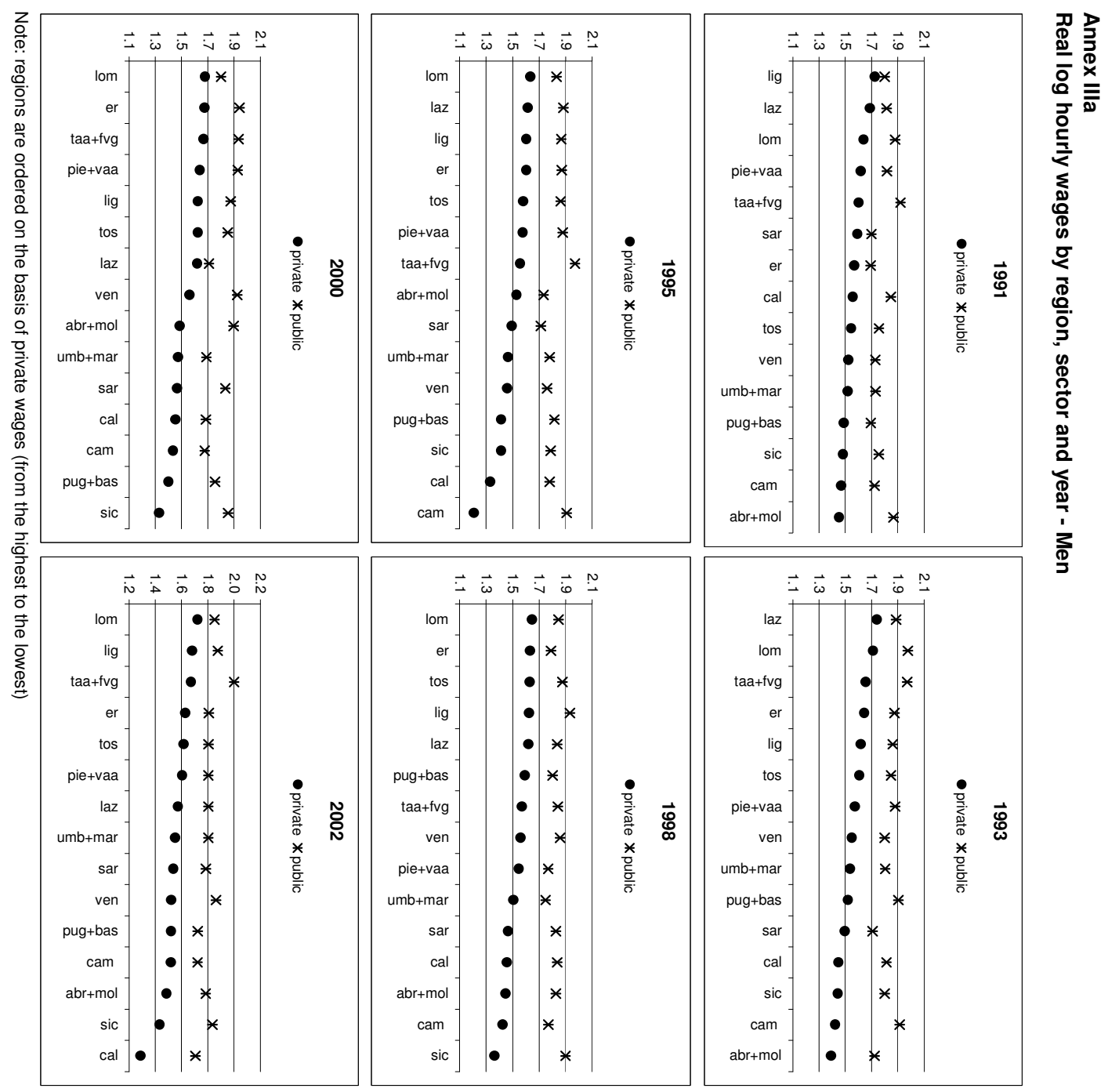


Annex IIIb

Real log hourly wages by region, sector and year - Women
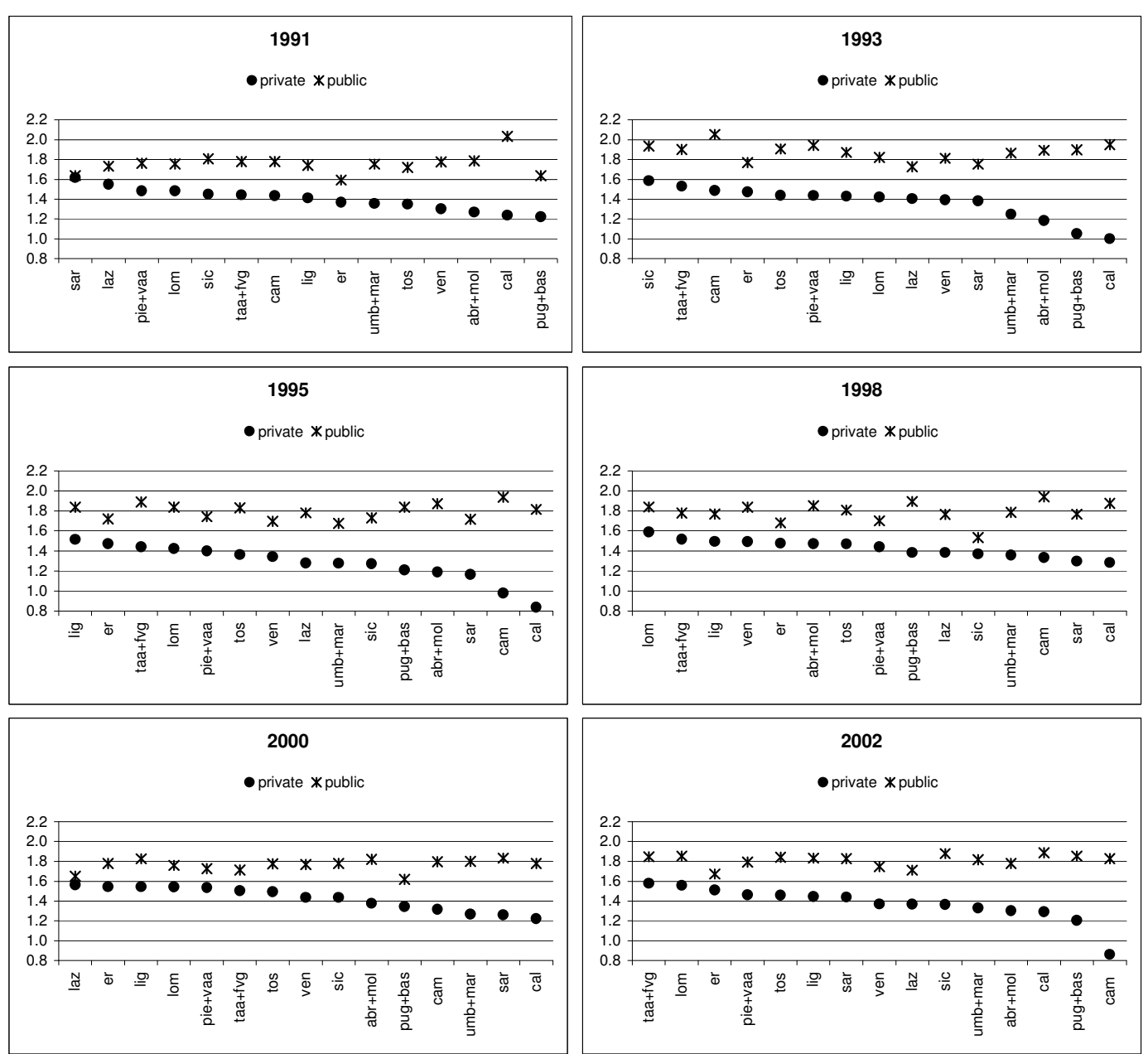

Note: regions are ordered on the basis of private wages (from the highest to the lowest) 
Annex IV

Public-private wage differentials by region, year and sex

(log public wage - log private wage)

\begin{tabular}{|c|c|c|c|c|c|c|}
\hline & \multicolumn{6}{|c|}{ Men and women } \\
\hline & 1991 & 1993 & 1995 & 1998 & 2000 & 2002 \\
\hline pie+vaa & 0.2153 & 0.3940 & 0.2826 & 0.2324 & 0.2199 & 0.2566 \\
\hline lom & 0.2237 & 0.2867 & 0.2753 & 0.2195 & 0.1528 & 0.1937 \\
\hline taa+fvg & 0.2974 & 0.3264 & 0.4088 & 0.2598 & 0.2131 & 0.2736 \\
\hline ven & 0.3129 & 0.3218 & 0.3255 & 0.3156 & 0.3381 & 0.3465 \\
\hline lig & 0.1359 & 0.3137 & 0.2730 & 0.2681 & 0.2613 & 0.2885 \\
\hline er & 0.1354 & 0.2270 & 0.2308 & 0.1506 & 0.2273 & 0.1609 \\
\hline tos & 0.2577 & 0.3283 & 0.3502 & 0.2757 & 0.2419 & 0.2739 \\
\hline$u m b+m a r$ & 0.2799 & 0.4152 & 0.3455 & 0.3273 & 0.3633 & 0.3540 \\
\hline laz & 0.1365 & 0.2010 & 0.3562 & 0.2702 & 0.0830 & 0.2698 \\
\hline $\mathrm{abr}+\mathrm{mol}$ & 0.4098 & 0.4774 & 0.3754 & 0.3549 & 0.4185 & 0.3711 \\
\hline cam & 0.2849 & 0.5324 & 0.7692 & 0.4401 & 0.3141 & 0.3815 \\
\hline pug+bas & 0.2251 & 0.4888 & 0.4445 & 0.3058 & 0.3249 & 0.3328 \\
\hline cal & 0.3683 & 0.5350 & 0.6015 & 0.4281 & 0.2920 & 0.5001 \\
\hline sic & 0.2986 & 0.3865 & 0.3795 & 0.3748 & 0.4756 & 0.4378 \\
\hline sar & 0.0676 & 0.2520 & 0.3108 & 0.3843 & 0.4429 & 0.3111 \\
\hline cv & 0.3743 & 0.2831 & 0.3513 & 0.2515 & 0.3583 & 0.2675 \\
\hline \multirow[t]{3}{*}{ ITALY } & 0.2306 & 0.3335 & 0.3509 & 0.2735 & 0.2348 & 0.2739 \\
\hline & \multicolumn{6}{|c|}{ Men } \\
\hline & 1991 & 1993 & 1995 & 1998 & 2000 & 2002 \\
\hline pie+vaa & 0.2014 & 0.3079 & 0.3040 & 0.2239 & 0.2913 & 0.2019 \\
\hline lom & 0.2423 & 0.2678 & 0.2008 & 0.2028 & 0.1235 & 0.1329 \\
\hline taa+fvg & 0.3215 & 0.3185 & 0.4163 & 0.2746 & 0.2693 & 0.3320 \\
\hline ven & 0.2075 & 0.2535 & 0.3026 & 0.3001 & 0.3643 & 0.3438 \\
\hline lig & 0.0783 & 0.2469 & 0.2663 & 0.3097 & 0.2516 & 0.1972 \\
\hline er & 0.1260 & 0.2315 & 0.2698 & 0.1604 & 0.2691 & 0.1820 \\
\hline tos & 0.2129 & 0.2451 & 0.2842 & 0.2477 & 0.2294 & 0.1918 \\
\hline$u m b+m a r$ & 0.2147 & 0.2709 & 0.3166 & 0.2451 & 0.2170 & 0.2541 \\
\hline laz & 0.1288 & 0.1494 & 0.2708 & 0.2185 & 0.0916 & 0.2342 \\
\hline $\mathrm{abr}+\mathrm{mol}$ & 0.4185 & 0.3334 & 0.2071 & 0.3826 & 0.4151 & 0.3023 \\
\hline cam & 0.2549 & 0.4932 & 0.7004 & 0.3469 & 0.2435 & 0.2072 \\
\hline pug+bas & 0.2088 & 0.3856 & 0.4032 & 0.2120 & 0.3568 & 0.2065 \\
\hline cal & 0.2910 & 0.3697 & 0.4504 & 0.3827 & 0.2337 & 0.4204 \\
\hline sic & 0.2756 & 0.3599 & 0.3761 & 0.5372 & 0.5275 & 0.4042 \\
\hline sar & 0.1095 & 0.2123 & 0.2210 & 0.3624 & 0.3699 & 0.2502 \\
\hline cv & 0.3897 & 0.2746 & 0.3682 & 0.3182 & 0.3772 & 0.3190 \\
\hline \multirow[t]{3}{*}{ ITALY } & 0.2029 & 0.2713 & 0.3067 & 0.2635 & 0.2225 & 0.2086 \\
\hline & \multicolumn{6}{|c|}{ Women } \\
\hline & 1991 & 1993 & 1995 & 1998 & 2000 & 2002 \\
\hline pie+vaa & 0.2794 & 0.5055 & 0.3428 & 0.2619 & 0.1922 & 0.3323 \\
\hline lom & 0.2743 & 0.4003 & 0.4134 & 0.2503 & 0.2185 & 0.2944 \\
\hline taa+fvg & 0.3373 & 0.3699 & 0.4478 & 0.2622 & 0.2121 & 0.2677 \\
\hline ven & 0.4739 & 0.4201 & 0.3547 & 0.3446 & 0.3336 & 0.3780 \\
\hline lig & 0.3299 & 0.4413 & 0.3222 & 0.2733 & 0.2826 & 0.3880 \\
\hline er & 0.2239 & 0.2953 & 0.2480 & 0.2037 & 0.2336 & 0.1632 \\
\hline tos & 0.3711 & 0.4681 & 0.4679 & 0.3376 & 0.2822 & 0.3833 \\
\hline$u m b+m a r$ & 0.3955 & 0.6175 & 0.3992 & 0.4268 & 0.5329 & 0.4881 \\
\hline laz & 0.1824 & 0.3218 & 0.5013 & 0.3825 & 0.0871 & 0.3437 \\
\hline $\mathrm{abr}+\mathrm{mol}$ & 0.5192 & 0.7092 & 0.6822 & 0.2779 & 0.4447 & 0.4766 \\
\hline cam & 0.3462 & 0.5676 & 0.9557 & 0.6065 & 0.4819 & 0.9688 \\
\hline pug+bas & 0.4154 & 0.8456 & 0.6273 & 0.5114 & 0.2755 & 0.6483 \\
\hline cal & 0.7952 & 0.9486 & 0.9779 & 0.5926 & 0.5559 & 0.5942 \\
\hline sic & 0.3571 & 0.3499 & 0.4580 & 0.1636 & 0.3424 & 0.5129 \\
\hline sar & 0.0206 & 0.3726 & 0.5517 & 0.4679 & 0.5730 & 0.3906 \\
\hline cv & 0.4674 & 0.3700 & 0.4023 & 0.3707 & 0.4259 & 0.4197 \\
\hline ITALY & 0.3222 & 0.4572 & 0.4476 & 0.3073 & 0.2675 & 0.3744 \\
\hline
\end{tabular}


Annex V

Regional indicators, 2002

\begin{tabular}{lrrrrrrrrr}
\hline & U rate & $\begin{array}{r}\text { Youth U } \\
\text { rate } \\
(15-24)\end{array}$ & $\begin{array}{r}\text { Women } \\
\text { activity } \\
\text { rate } \\
\text { (c) }\end{array}$ & $\begin{array}{r}\text { \% public } \\
\text { employ- } \\
\text { ment } \\
\text { (d) }\end{array}$ & $\begin{array}{r}\text { irregular } \\
\text { employ- } \\
\text { ment } \\
(\mathrm{e})\end{array}$ & $\begin{array}{r}\text { days of } \\
\text { rain }\end{array}$ & $\begin{array}{r}\text { p house } \\
\text { (euros) }\end{array}$ & crime rate life quality \\
& $(\mathrm{f})$ & $(\mathrm{f})$ & $(\mathrm{h})$ & $(\mathrm{i})$ \\
\hline pie+vaa & 5.1 & 13.9 & 56.0 & 22.9 & 13.6 & 84 & 2029 & 72.9 & 483.0 \\
lom & 3.8 & 10.2 & 55.1 & 21.7 & 10.8 & 72 & 3538 & 54.8 & 503.9 \\
taa+fvg & 3.2 & 6.4 & 56.0 & 26.9 & 13.0 & 92 & 1979 & 33.2 & 521.4 \\
ven & 3.4 & 7.1 & 53.7 & 20.6 & 11.4 & 77 & 2083 & 31.9 & 498.7 \\
lig & 6.4 & 21.8 & 51.6 & 28.7 & 12.7 & 69 & 1689 & 68.6 & 489.6 \\
er & 3.3 & 8.0 & 62.0 & 22.4 & 10.3 & 70 & 2787 & 41.4 & 503.6 \\
tos & 4.8 & 14.8 & 54.9 & 25.1 & 12.3 & 91 & 3116 & 48.5 & 497.2 \\
umb+mar & 4.9 & 11.3 & 55.2 & 24.6 & 14.4 & 80 & 1980 & 35.1 & 483.9 \\
laz & 8.6 & 29.9 & 47.0 & 34.2 & 17.7 & 70 & 2780 & 68.7 & 465.3 \\
abr+mol & 7.5 & 21.8 & 45.8 & 31.4 & 17.3 & 75 & 1800 & 42.7 & 473.8 \\
cam & 21.1 & 57.0 & 35.1 & 35.0 & 25.2 & 63 & 2172 & 61.4 & 426.1 \\
pug+bas & 14.1 & 36.8 & 35.4 & 30.6 & 21.1 & 71 & 1839 & 32.2 & 422.0 \\
cal & 24.6 & 56.5 & 41.4 & 36.3 & 29.1 & 58 & 1324 & 41.7 & 440.7 \\
sic & 20.1 & 50.1 & 34.3 & 37.3 & 24.0 & 57 & 1368 & 43.8 & 412.3 \\
sar & 18.5 & 45.8 & 42.8 & 32.2 & 19.8 & 91 & 1582 & 42.4 & 466.0 \\
\hline
\end{tabular}

(f) number of days of rain during the year, average 1994-99

(g) price per squared meter of new houses in regional capital cities

(h) number of crimes in 1000 inhabitants

(i) composite indicator (ranging from 0 to 600) on the overall quality of life computed for each Italian province by the economic newspaper "II Sole 24 Ore"; regional average. The overall indicator summarizes six different aspects: demographic indicators, standard of living, business and labour markets, environment and quality of local public services, crime and leisure. 